\title{
COPYRIGHT PROTECTION FOR ARCHITECTURE A AFTER THE ARCHITECTURAL WORKS COPYRIGHT PROTECTION ACT OF 1990
}

\author{
RAPHAEL WINICK
}

\section{INTRODUCTION}

On December 1, 1990, President Bush signed into law the Architectural Works Copyright Protection Act (AWCPA). ${ }^{1}$ The AWCPA implements an important change in the treatinent of architecture under American intellectual property law, exphicitly extending American copyright protection, for the first time, to completed architectural works.

The AWCPA extends protection to a very broad class of architectural works. ${ }^{2}$ However, Congress carefully limited the scope of the protection enjoyed by these works. ${ }^{3}$ The interplay between the AWCPA's broad subject matter and its limited protection presents several interpretive questions. Furthermore, problems of substantial similarity, ${ }^{4}$ appropriate forms of rehef, ${ }^{5}$ works for hire, ${ }^{6}$ joint authorship, ${ }^{7}$ and assignment of rights ${ }^{8}$ are only a few of the questions likely to arise.

1. Pub. L. No. 101-650, $\S \S 701-706,104$ Stat. 5133 (1990) (codified at scattered sections of 17 U.S.C.A.) (West Supp. 1992). Congress passed the AWCPA as part of the Judicial Improvements Act of 1990, Pub. L. No. 101-650, along with two other important pieces of intellectual property protection, the Visual Artists Rights Act of 1990, Pub. L. No. 101-650, $\S \S 601-610,104$ Stat. 5128 (1990) (codified at scattered sections of 17 U.S.C.A.) (West Supp. 1992), and the Computer Software Rental Amendment Act of 1990, Pub. L. No. 101-650, $\S 801-805$, 104 Stat. 5134 (1990) (codified at scattered sections of 17 U.S.C.A) (West Supp. 1992). The Visual Artists Rights Act grants certain visual artists the rights of "attribution" and "integrity." The right of attribution ensures that artists are correctly identified with the works they create. The right of integrity allows these artists to protect their works against modifications and destruction that are prejudicial to their honor or reputations. See generally Robert Gorman, The Visual Artists Rights Act of 1990, 38 J. CoPYR1GHT Soc'y 233 (1991). The Computer Software Rental Amendment Act grants computer software an exception to the "first sale" doctrine of copyright, preventing the owners of computer software from renting, lending, or leasing their programs for commercial advantage. Taken together, these three pieces of legislation represent the inost significant revisions to American intellectual property law since the Copyright Act of 1976.

2. See infra Parts II(C)-(F).

3. See infra Part III.

4. See infra Part IV(A).

5. See infra Part III(C).

6. See infra Part IV(B)(1).

7. See infra Part IV(B)(2).

8. See infra Part IV(B)(3). 
This Note, intended as a guide to the provisions of the AWCPA, inakes several specific recommendations to the courts and the practitioners who will be asked to craft an interpretive framework for the AWCPA. For the AWCPA to serve effectively the needs of society and the architectural profession, courts inust carefully limit the scope of copyright protection of architectural works. Interpreters of the AWCPA inust not overextend the AWCPA as if it were the only form of intellectual property protection for architecture. Indeed, as will be shown, the AWCPA provides only a small portion of the proteetion needed to stimulate the creativity of the architectural profession. The AWCPA should be viewed as a discrete part of a larger, more comprehensive scheme of intellectual property protection for architecture; as such, it should not be allowed to encroach upon the doinain of patent, tradenark, and local historic preservation laws.

This Note concludes that the AWCPA, and the inulti-faceted scheme of intellectual property protection for architecture of which it is a part, is well tailored to protect the societal interest in architectural creativity. Progress and creativity in the architectural profession are best served by limiting the copyright protection available to architectural works. Additionally, the approach taken by Congress yields useful lessons for possible reform of the law governing other types of apphed art.

\section{BACKgRoUnd OF THE ARCHITECTURAL WORKS Copyright Protection ACT}

\section{A. Architecture, Society, and the Purposes of Copyright Law}

The importance of architecture as an art form is unquestioned. ${ }^{9}$ For thousands of years, western cultures considered architecture their single inost important art form. ${ }^{10}$ Architects throughout history have viewed their craft as both expressing and driving culture. ${ }^{11}$ Architecture and

9. See Walter Gropius, The New Architecture and the Bauhaus 39-40 (P. Shand Morton trans., 1935) ("Architecture and design in a general sense are consequently matters of paramount concern to the nation at large."). Gropius, one of the great fignres in twentieth-century architecture, also urged against the perception of architecture as somehow less valuable artistically than the other arts, calling this "one of our fatal legacies from a generation which arbitrarily elevated some of its branches above the rest as the "Fine Arts." Id.

10. See, e.g., Talbot Hamlin, ArChitecrure Throvgh the Ages 30, 115, 153 (rev. ed. 1953) (tracing the central place of architecture in society from the culture of ancient Egypt through the Renaissance and beyond). Only during the Renaissance did painting and sculpture emerge as rivals to architecture in artistic significance. See id. at 324.

11. See Gropius, supra note 9, at 17-18 ("A breach has becn made with the past, which allows us to envisage a new aspect of architecture corresponding to the technical civilization of the age we live in; ... although the outward forms of the New Architecture differ fundamentally in an organic sense from those of the old, they are not the personal whims of a handful of architects ... but simply the inevitable logical product of the intellectual, social and technical conditions of our age."). 
society have a profoundly interdependent relationship. Architecture expresses the values of its cultural context; at the same time it helps create the culture that it inhabits. ${ }^{12}$

Architecture plays inore than just an aesthetic role in society. For example, architecture performs invaluable utilitarian functions: Intelligent and creative architectural design inakes everyday tasks infinitely easier. Architecture is also one of the inost important service industries in the United States. ${ }^{13}$ In addition to its direct econonic importance, architecture also promotes scientific advancenient: The needs of architecture provided the impetuses for such varied technical advancenients as the flush toilet, the elevator, reinforced concrete, plate glass, and the air conditioner, to name only a few. ${ }^{14}$

The social importance of architecture led nost European nations to extend soine copyright protection to architectural works. ${ }^{15}$ The scope of the protection offered by these nations ranges froin quite limited to very broad protection. ${ }^{16}$ In contrast, the United States has continually resisted extending copyright protection to architecture. ${ }^{17}$

American reluctance to extend copyright protection to architecture originated in the policy objective that drives American copyright law. Unlike European copyright laws, which are grounded in the natural rights of authors in their works, ${ }^{18}$ American intellectual property laws serve the constitutionally mandated purpose, "To proinote the Progress

12. See Robert A.M. Stern, New Directions in Architecture 7 (1977) (discussing the Modernist architects of the first part of this century, who deeply believed in the ability of architects to mold and improve lifestyles and transform society).

13. The architectural and engineering professions grossed revenues of over $\$ 62$ billion in 1988 and more than $\$ 73$ billion in 1989. Census BuREAU, U.S. DePARTMENT OF COMMERCE, 1991 Statistical ABstract OF THE UNITEd States 785 (1991) (Table No. 1380).

14. JOSEPH HUdNUT, ARCHITECTURE AND THE SPIRIT OF MAN 220-30 (1949).

15. Sam Ricketson, The Berne Convention for the Protection of Literary and ARTISTIC WoRks: 1886-1986, at 253-57 (1987); Natalie Wargo, Note, Copyright Protection for Architecture and the Berne Convention, 65 N.Y.U. L. REv. 403, $409-12$ (1990).

16. Wargo, supra note 15, at 413-39. The Berne Convention does not mandate completely uniform copyright laws among member nations. Wargo's note provides an excellent review of the different intelleetual property protections offered to architectural works by the various member nations of the Berne Convention.

17. See Copyright in Works of ARchitecture: Report of the Register of COPYRIGHTS 71-140 (1989) [heremafter COPYRIGHT OFFICE REPORT] (reviewing various failed attempts from 1905 to 1988 to add architecture to subject matter of copyright law).

18. Berne Convention for the Protection of Literary and Artistic Property, Sept. 9, 1886, art. 6bis, 828 U.N.T.S. 221, 235 (Paris revision, July 24, 1971) [hereinafter Berne Convention]. By basing their laws on an inherent natural right of authors to claim authorship and to control exploitation of the works that they create, the intellectual property laws of most European and many other nations are broader in scope than American intellectual property laws. For example, the Berne nations recognize the rights of patermity and integrity for copyrighted works, regardless of the effect of these rights on society. See id. This contrasts with American copyright law, which subordinates the needs of artists to the needs of society. See infra note 20 and aecompanying text. 
of Science and useful Arts, by securing for limited Times to Authors and Inventors the exclusive Right to their respective Writings and Discoveries."19 Consistent with this constitutional objective, American intellectual property law is based on benefiting the public, not the artist. ${ }^{20}$ Copyright and patent protection are not rights, but rather privileges, statutorily granted to serve the interests of society in encouraging artistic and scientific advanceinent. ${ }^{21}$ The limited inonopoly granted to authors and inventors is granted only to provide an incentive for further creativity. 22 As stated by the Suprene Court:

The monopoly privileges that Congress may authorize are neither unlimited nor primarily designed to provide a special private benefit. Rather, the limited grant is a means by which an important public purpose may be achieved. It is intended to motivate the creative activity of authors and inventors by the provision of a special reward, and to allow the public access to the products of their genius after the limited period of exclusive control has expired.23

Prior to 1990, Congress resisted extension of copyright protection to architectural works, on the theory that such protection would not encourage creativity in the architectural profession. This failure to extend

19. U.S. CoNST. art. I, $\$ 8$, c1. 8. This clause provides the basis for federal patent and copyright legislation. The federal trademark regulations codified in the Lanham Act, 15 U.S.C. $\$ \$ 1051-1127$ (1988), are based on the Congressional power to regulate interstate commerce, U.S. CoNST. art. I, $\S 8, \mathrm{cl} .3$. Trademark law is generally categorized as a type of unfair competition regulation, and not as a form of intellectual property protection. Despite these different constitutional origins, this Note discusses trademark alongside patent and copyright law.

20. Twentieth Century Music Corp. v. Aiken, 422 U.S. 151, 156 (1975) ("Creative work is to be encouraged and rewarded, but private motivation must ultimately serve the cause of promoting broad public availability of hterature, inusic, and the other arts. ... [T] he ultimate ain is, by this incentive, to stimulate artistic creativity for the general public good."); Mazer v. Stein, 347 U.S. 201, 219 (1954) ("The economic philosophy behind the clause empowering Congress to grant patents and copyrights is the conviction that encouragenent of individual effort by personal gain is the best way to advance public welfare through the talents of authors and inventors in 'Science and useful Arts." ").

21. This fundamental purpose remains unchanged notwithstanding the American decision to join tlie Berne Convention, an international intellectual property treaty that recognizes the moral riglits of an author in the works le produces. (For a description of the Berne Convention, see infra note 25.) Congress has made it very clear that the United States' decision to join Berne in no way indicates an acceptance of the idea of moral rights. See S. REP. No. 352, 100th Cong., 2d Sess. 10 (1988), reprinted in 1988 U.S.C.C.A.N. 3706, 3715 (American adherence to Berne Convention not intended to change the status quo regarding moral rights). However, recent lively Congressional debate over the colorization of motion pictures and the enactnent of the Visual Artists Rights Act of 1990 represent some small movement towards the recognition of moral rights under American intellectual property law. See, e.g., H.R. 2400, 100th Cong., 1st Sess. (1987) (unenacted bill preventing unauthorized colorization of black-and-white motion pictures); Filin Disclosure Act of 1992, S. 2256, 102nd Cong., 2d Sess. (1992) (pending legislation requiring colorized films to bear notice that film has been altered); Visual Artists Rights Act of 1990, Pub. L. No. 101-650, $\S 601-610,104$ Stat. 5128 (1990) (codified at scattered seetions of 17 U.S.C.A.) (West Supp. 1992).

22. Twentieth Century Music, 422 U.S. at 156.

23. Sony Corp. of Am. v. Universal City Studios, Inc., 464 U.S. 417, 429 (1984). 
protection was based on the idea that architecture was a utilitarian work, and therefore not worthy of copyright protection. ${ }^{24}$ American intellectual property law does not protect utilitarian works, beheving that progress and creativity are retarded by preventing useful objects froin being available to others to use, adapt, or nodify.

The decision by the United States in the 1980s to becoine a nieinber of the Berne Convention for the Protection of Literary and Artistic Works (the Berne Convention) ${ }^{25}$ forced a reexamination of the conception of architecture as a utilitarian work under American law. ${ }^{26}$ Congress determined that in order for the United States to coinply fully with

24. Useful articles, that is, those works that share both an artistic and a utilitarian nature, have proven the most difficult works to fit within the former Copyright Act of 1909, 35 Stat. 1075 (1909), or the current Copyright Act of 1976, 17 U.S.C. $\$ \S 101-914$ (1988). Works having dual artistic and utilitarian roles present conceptual difficulties for an intellectual property regime that draws many of its substantive distinctions between artistic expression and utilitarian function. The "separability test" is the tool used to shape coherent copyright doctrine in the field of useful articles. The Copyright Act of 1976 codified the separability test, which states that if a pictorial, graphic, or sculptural work is of primarily utilitarian function, only its nonfunctional elements are eligible for copyright protection. 17 U.S.C. $\$ 101$ (1988) (definition of pictorial, graphic, or sculptural works); see also COPYRIGHT OFFICE, LIBRARY OF CONGRESS, COMPENDIUM II: COMPENDIUM OF COPYRIGHT OFFICE PRACTICES, ๆ 505, at 505.03 (1984) (describing standards used by Copyright Office in applying the separability test to three-dimensional useful articles); Louis Altman, Intellectual Property Law and the Construction Industry, Part II, 71 J. Pat. \& TRAdemark OFF. Soc'y 600, 650-54 (1989) (discussing cases in which building design was held to be protectible).

Despite the secming simplicity of the separability test, it has proven difficult to apply in practice. Courts have struggled to delineate the dividing "line betwecn unprotectible industrial designs and protectible pictorial, graphic, and scnlptural works." Architectural Design Protection: Hearings on H.R. 3990 and 3991 Before the Subcomm. on Courts, Intellectual Property and the Administration of Justice of the House Comm. on the Judiciary, 101st Cong., 2d Sess. 60-61 (1990) [hereinafter Hearings on the AWCPA] (statement of Ralph Oman, Register of Copyrights). Consensus in the application of the test has been elusive, and the cases have generated many disputed opinions. Kieselstein-Cord v. Accessories by Pearl, Inc., 632 F.2d 989 (2d Cir. 1980), and Carol Barnhart Inc. v. Economy Cover Corp., 773 F.2d 411 (2d Cir. 1985), are two of the most significant cases. The circuit court panels in both of these cases split 2-1, and the decisions included vigorous and carefully reasoned dissents. Both the majority opinions and the dissents have generated well-founded favorable commentary. For a review of the separability test and different attempts to come to grips with its application, see Shira Perlmutter, Conceptual Separability and Copyright in the Designs of Useful Articles, 37 J. COPYright Soc'Y 339 (1990).

25. Supra note 18, 828 U.N.T.S. at 221. The Berne Convention is the most important of the international copyright treaties. Originally adopted in 1886 , the Convention is currently accepted by eighty-five nations, including all industrialized nations except China and Russia. For a detailed history of the Berne Convention, see RickeTson, supra note 15. The most important provision of the Berne Convention is its guarantee that foreign copyright holders will be able to appear before the courts of another siguatory nation to allege piracy of their copyrighted work. Berne Convention, supra note 18, art. 5, para. 1, 828 U.N.T.S. at 223.

26. Although the United States had considered joining the Berne Convention on several occasions, it was not until the mid-1980s that the United States decided to join. Substantive differences between the Convention and existing American copyrigltt law caused the American reluctance to join the agrecment. The Berne Convention has a broader subject matter definition than U.S. copyright law, compare Berne Convention, supra note 18, art. 2, para. 1, 828 U.N.T.S. at 227 with 17 
the Berne Convention-which protects architecture alongside other artistic works ${ }^{27}$-American copyright law would have to recognize the artistic value of architecture by extending copyright protection to architectural works. ${ }^{28}$

Any protection offered by the AWCPA must ultimately serve the constitutional objectives of our intellectual property laws. ${ }^{29}$ Interpreters of the AWCPA and related provisions of the copyright and patent laws must therefore be conscious of how a system of legal protections can help encourage artistic and scientific progress in architectural design. ${ }^{30}$

On the other hand, mterpreters of the AWCPA must be cognizant of the fact that overbroad copyright protection of architectural works will frustrate, rather than advance, the purpose of the copyright laws. ${ }^{31}$ Extension of the AWCPA beyond its carefully limited scope will retard progress and creativity in the architectural profession. The architectural design process relies upon the process of limited copying and imcremental innovation; that is, it depends upon some degree of copying from past forms. This process is one that the AWCPA's interpreters must comprehend and respect.

U.S.C. $\$ 102(a)$ (1988); it gives authors greater control of subsequent use of their works, Berne Convention, supra note 18, art. 5, para. 2, 828 U.N.T.S. at 223; and it dispenses with formalities, Berne Convention, supra note 18, art. 6 bis, 828 U.N.T.S. at 235. Most troubling to American copyright law is the Convention's recognition of the "moral rights" of authors in their works. Id. Import considerations created another barrier to American adherence. 134 Cong. Rec. S14,557 (daily ed. Oct. 5, 1988) (stateinent of Sen. Orrin G. Hatch).

27. For a discussion of the protection required under the Berne Convention, see infra notes 64 67 and accompanying text.

28. Not all copyright scholars agreed that the Berne Convention mandated the changes in the Copyright Act that became the AWCPA. See infra notes 63-67 and accompanying text for a discussion of this point.

29. Jurists have long debated the appropriate way to interpret statutes, without reaching any consensus. However, almost all of them agrec that the policy objectives of a law must play a signifcant role in interpreting that statute. See, e.g., Dickersou v. New Banner Inst., Inc., 460 U.S. 103 (1983) (statutory interpretation must be guided by the plain language of the statute and by the policy objectives underlying its provisious).

30. But it does not necessarily follow that once an art form is recognized as important to society, it should automatically be accorded broad legal protection. See Stephen Breyer, The Uneasy Case for Copyright: A Study of Copyright in Books, Photocopies, and Computer Programs, 84 HaRv. L. REV. 281, 284-91 (1970) (arguing that increased copyright protection is not necessary to create incentives for origulal artistic expression); Liuda J. Lacey, Of Bread and Roses and Copyrights, 1989 DUKE L.J. 1532 (examining incentives for artists to create, and how legal norms can best provide such incentives).

31. American courts have consistently ruled that intellectual property rights should be withheld if granting such rights would hinder progress and creativity. See Mazer v. Stein, 347 U.S. 201, 217-19 (1954) (holding that allowing copyright in the functional elements of a lamp would hiuder creativity and progress in the useful arts); Atlantic Works v. Brady, 107 U.S. 192, 200 (1882) (holding that allowing patent in "every trifing device" or technological advance was never the purpose of patent law). 


\section{B. Creativity and the Architectural Design Process}

An examination of the interrelationship between architecture, society, creativity, and the design process demonstrates that architectural creativity consists of the recombination of separate elements into forms that express both the new context of the work and the originality of the architect. Legal norms that encourage incremental innovation and novel recoinbination of existing forms will foster such creativity, and benefit society.

Architects rarely come up with wholly original designs. Designs for buildings do not emerge fully conceived from the imagination of architects as Athena sprang from the head of Zeus. Solne borrowing from existing sources is absolutely essential. ${ }^{32}$ The character of a building is created by the combination of different elements in a specific context. These elements can include a brick wall, an arch, a bay window, a inarble floor, an asymmetrical corner, and a curtain wall of glass to create the illusion of space, to name only a fraction of the individual eleinents available for use in an architectural design. Known as the architectural "vocabnlary," these elements may be either familiar or unfamiliar, and can be coinbined in an almost infinite variety of ways.

Fignre 1, which appears as an appendix to this Note, is taken from the interior of an English inanor of the eighteenth century. The example identifies soine of the inany individual elements selected and arranged by the architects. Taken individually, none of these elements are original. Entire sections of the work, when viewed in isolation, such as the ceiling or the colonnade, bear striking similarities to previous works. However, these sections are subsumed into an original and harmonious whole when combined with the other sections of the work.

Cesar Pelli's World Financial Center in New York City (Figure 2) provides a more recent example of the same principles. Pelli recounbines basic elements of inodern skyscraper architecture-the glass curtain wall, setback design, enclosed glass atriums, and sheer granite walls with flush windows-to create a distimctive work. The four buildings have sheer gramite walls for the lower floors, which gradually take on inore glass surface at each setback. Setbacks are positioned to inaximize lines of sight for surrounding buildings and serve to inake the proportions of these eleinents the focus of the design. Atop the sleek inodern forms of each building, Pelli juxtaposes the historicist eleinent of a pyramidal or

32. See Elizabeth K. Brainard, Note, Innovation and Imitation: Artistic Advance and the Legal Protection of Architectural Works, 70 CORNELL L. Rev. 81, 92 (1984); Joseph Giovannini, Architectural Imitation: Is It Plagiarism?, N.Y. TIMES, Mar. 17, 1983, at C1. 
doined top. Again, it is the architect's choice of the combination of elements that creates the character of the work.

As the above examples illustrate, architectural creativity consists of appropriating elements from the architectural vocabulary, ${ }^{33}$ and rearranging them in a more useful or more aesthetically pleasing way. ${ }^{34}$ The incremental innovation that can transform art may be very slow and subtle. Originality and creativity can take as limited a form as placing an existing design im a new context. ${ }^{35}$ A unique combination of borrowed elements from a series of designs may represent an artistic advance. ${ }^{36}$ Sinall alterations im a previous design may constitute a significant utilitarian or aesthetic advance. Courts must therefore refram from acting on the assuunption that creativity is mutually exclusive of copying.

In governing an art form that rehes on copying, intellectual property law faces a dilemma. On one hand, the law must provide protection to architects, in order to encourage them to recombine existing elements in increasingly useful ways and to create new imdividual elements that will add to the creativity of their profession. On the other hand, the law must not protect too much, such that other architects will be deprived of the use of existing forms and of the chance to adapt them for use $i m$ other contexts. Thus the difficulty for intellectual property law is determining

33. See James M. Fitch, AMERican BuILding: The Historical Forces That Shaped It (1973); Brainard, supra note 32, at 92-95. Robert A.M. Stern, one of the most influential American architects of the past thirty years, has stated: "As long as the source is good, I steal. Not in the sense of taking away from another architect-he is not poorer because of a theft but is in fact more influential. We copy, borrow, and derive motifs from other architects. Artists have always quoted other artists." Giovannimi, supra note 32 , at $\mathrm{Cl}, \mathrm{C} 6$.

34. 'Lines, curves, angles, and squares are some of the 'geonetric words' used by an architect in his technieal writings. ... Every architectural plan, drawing, and design is an amalgam of lines, curves, angles, and squares. ... It is the arrangement of the lines, curves, angles, and squares which enables the architect to express his artistic personality." Arthur S. Katz, Copyright Protection of Architectural Plans, Drawings, and Designs, 19 LAW \& CONTEMP. ProBs. 224, 242 (1954); see also Park-In-Theatres, Inc. v. Perkins, 190 F.2d 137, 139-42 (9th Cir. 1951) (novelty for purposes of patent law can result from combination of disparate unpatentable eleinents); Loew's Drive-In Theatres, Inc. v. Park-In Theatres, Inc., 174 F.2d 547 (1st Cir.), cert. denied, 338 U.S. 822 (1949).

35. For example, the AT\&T building in New York City has a unique and powerful presence on the Manhattan skyline by virtue of architect Philip Johnson's use of a familiar form, the "Chippendale" broken pediment normally used in interior architecture and furniture, in the unfamiliar setting of the top of a skyscraper. Similarly, Johnson used the familiar pointed turrets and flying buttresses of Gothic architecture to create the PPG complex in Pittsburgh. The originality of the design of the PPG buildings lies in the fact that the familiar forms, usually created out of stone, are instead rendered in the unfamiliar material of glass.

However, it should be noted that in the field of music, courts have been unwilling to aceept arguments that infringement does not consist in borrowing existing forms and placing them into new contexts. See, e.g., Grand Upright Music Ltd. v. Warner Bros. Records, 780 F. Supp. 182, 185 (S.D.N.Y. 1991) (holding that hip-hop artist infringed musical copyright by "sampling" easy-listening song to use in rap song).

36. Brainard, supra note 32 , at $93-94$. 
at what point the novel recoinbination of preexisting ideas should constitute protectible artistic expression.

The architectural profession already has many independent incentives to creativity. The presence of such incentives argues against broad intellectual property law protection for architectural works. Regarding the limited monopolies American copyright law grants artists in their creations, the Supreme Court has stated, "the economic philosophy belimd the [copyright clause of the Constitution] is the conviction that encouragement of individual effort by personal gain is the best way to advance public welfare ...."37 Architects, however, often do not need limited monopolies in their creations in order to receive personal gain. These monopolies are highly appropriate for works sucl as literary and musical works that "lack autonomous means of appropriating the fruits of [the artist's] higli-risk investment in creations that attain commercial success." 38 In contrast, $m$ the architectural profession the creative mind possesses independent means for recouping the costs of innovation. Architects rarely price their services on the assumption that a desigu will be copied and reused. The cost of one set of architectural plans almost always mcludes the architect's total costs incurred on that project, plus a reasonable profit. This contrasts with books and musical recordings, for which the sale of only one copy usually would not cover the cost of production.

So in the area of architecture that values creativity most highly, namely the area of one-time, high-profile projects in major competitions, an architect will likely have sufficient incentive to be creative. The financial reward to the architect for being creative will be provided by winning the commission, not by later reproductions of the work. ${ }^{39}$ This is also the area of the profession that may benefit inost from a broad allowance of self-referential "quoting" from other architectural sources.

On the other hand, the type of architectural work that would benefit from intellectual property law protection is that which is easily reproducible and therefore particularly vuhierable to free riders. Architects who generate reproducible desigus would have greater incentives for creativity if reproductions of their designs provided them with financial reward. Indeed, the more reproducible a building is, the more likely it is that the

37. Mazer v. Stein, 347 U.S. 201, 219 (1954).

38. J.H. Reichmann, Design Protection and the Legislative Agenda, LAw \& ContEMP. Pross., Spring 1992, at 281, 291; see J.H. Reichmann, Design Protection and the New Technologies: The United States Experience in a Transnational Perspective, 19 U. BALT. L. REv. 6, 135-44 (1989).

39. It would be these later reproductions that patent, copyright, and trademark law would regulate. 
architect designed the building with the economic incentive of reproductions in mind. To allow direct copying of, for example, single-family houses and sinall- or inediun-sized industrial buildings, which are the inost likely to be built around standardized plans, would be to diminish an architect's economic incentive to create popular, standardized works. But again, architects usually price their services with the assumption that their designs will not be copied and reused, and thus do not depend on intellectual property law protection for incentives to creativity.

An additional arguinent against broad intellectual property protection for architecture is that the profession is regulated by itself and by the market. More than other artistic professions, architecture is dependent on individual chents. ${ }^{40}$ As a practical matter, the party that commissions an architectural work will have inuch greater input in the work produced than would the consumers of other types of copyrightable works. ${ }^{41}$ Although the peers of an architect may value originality and creativity, the client inay not. ${ }^{42}$ Even the most highly respected architect inust find a chent in order to construct a design. ${ }^{43}$ A survey of 600 large commercial architectural chents found that the professional qualities that led these chents to hire a particular architectural firm were: the ability to coinplete a project on budget, the ability to make a building function, the ability to complete a desigu on time, and the ability to work with the chent. ${ }^{44}$ Aesthetic quality, within which creativity would be imcluded,

40. Dana Cuff, ARchitecture: The Story of Practice 33 (1991); Magali S. Larson et al., The Professional Supply of Designs: A Descriptive Study of Architectural Firms, in ProfessionALS AND URBAN Form 251, 252 (Judith R. Blau et al. eds., 1983); Magali S. Larson, Emblem and Exception: The Historical Definition of the Architect's Professional Role, in Professionals AND URBAN FORM, supra, at 49, 50.

41. Compare, for example, the standard form contracts for recording artists or authors of books, which give the artist far greater creative control over the work, with the standard contracts used in the architectural profession. Compare ENTERTAINMENT INDUSTRY CoNTRACTS: NeGotiATING AND DRAFTING GUIDE Form 160-1, cls. 3.01, 4.01 (Donald C. Farber gen. ed., 1991) (form recording contract commonly leaves recording artist with broad artistic control over completed work so long as work is commercially or technically satisfactory) with American Institute of Architects, Document B141, Standard Form of Agrecment Between Owner and Architect art. 2 (14th ed. 1987) [hereinafter AIA Standard Form Contract] (owner of building participates in, and must assent to, all aspects of design), reprinted in AMERICAN BAR Association, DESIGN AND CONSTRUCTION CONTRACTS 87 (1988).

42. Larson et al., supra note 40 , suggest that small architectural firms may value user satisfaction and long-lasting aesthetic value inore than large firms, which are reported to be inore sensitive to economic needs and efficiencies. Id. at 274 (citing Judith Blau, Beautiful Buildings and Breaching the Laws, 12 J. Soc. 110, 127 (1970)).

43. As the great Philip Johnson, principal designer of such works as the AT\&T Building in New York, the Pittsburgh Plate Glass Center in Pittsburgh, and the IDS Center in Minneapolis stated: "[M]aking more money . . . is, really, the first consideration of any architect." David W. Dunlap, $A$ Graceful Move 'Upstairs', N.Y. Times, May 23, 1982, § 8, at 6.

44. CuFf, supra note 40 , at 55 . 
ranked tenth in this survey, inentioned by only $21 \%$ of those surveyed. ${ }^{45}$ Clearly, the architectural market cannot be rehed upon to deter copying and to encourage creativity. Yet the fact reinains that the architectural inarket values creativity.46 Architects who exhibit originality in their works will be inore valued by their market, and annong their peers, than those who do not. 47

Different types of architectural works have different incentives for creativity. Creativity in soine of these works will be greatly assisted by the economic incentives provided by the copyright laws. Although protection is needed, this protection inust recognize the realities of architectural design. Architectural creativity takes inany forms. More so than soine of the other arts, architecture rehes upon soine copying of existing forms at almost all levels. Overbroad copyright protection will stifle, rather than proinote, creativity.

\section{Subject Matter of the Architectural Works COPYRIGHT Protection ACT}

\section{A. The State of the Law Prior to the Architectural Works Copyright Protection Act}

The core provisions of the AWCPA, sections 702(a) and 703 of Pubhic Law 101-650, amend the Copyright Act of 1976 to include "architectural works" within the subject inatter protected by the Act.48 Prior to the AWCPA, copyright law did not protect coinpleted buildings froin infringennent. ${ }^{49}$ Only architectural plans received copyright protection..$^{50}$

45. Id.

46. James B. Bucher, Comment, Reinforcing the Foundation, The Case Against Copyright Protection for Works of Architecture, 39 EMORY L.J. 1261, 1269 (1990) (citing JUDITH R. BLAU, ARChitects and Firms: A Sociological Perspective on Architectural Practice 13 (1984)).

47. Bucher, supra note 46, at 1269; Larson et al., supra note 40, at 273-75.

48. Prior to amendment by the AWCPA, $\S 102$ (a) of the Copyright Act of 1976 read:

(a) Copyright protection subsists, in accordance with this title, in original works of authorship fixed in any tangible medium of expression, now known or later developed, from which they can be perceived, reproduced, or otherwise communicated, either directly or with the aid of a machine or device. Works of authorship include the following categories:

(1) literary works;

(2) musical works, including any accompanying words;

(3) dramatic works, including any accompanying inusic;

(4) pantomimes and chorcographic works;

(5) pictorial, graphic, and sculptural works;

(6) motion pictures and other audiovisual works; and

(7) sound recordings.

17 U.S.C. $\S 102$ (a) (1988). The terms used in $\S 102$ (a) are defined in $\S 101$.

49. Although it protected architectural plans, the Copyright Act did not have a subject matter category that protected completed threc-dimensional architectural works. Coinpleted structures were instead considered "useful articles" and were therefore subject to the separability test discussed supra note 24. See Donald Frederick Evans \& Assocs. v. Continental Hoines Inc., 785 F.2d 897, 901 n.7 (11th Cir. 1986). 
Pre-AWCPA caselaw firmly established that architectural plans, drawings, and models are subject to copyright. ${ }^{51}$ However, three-dimensional completed structures could not be copyrighted. ${ }^{52}$ The troubling result was that the unauthorized construction of a building from copyrighted plans did not constitute infringement. 53

50. Section 5(i) of the 1909 Copyright Act included "[d]rawings or plastic works of a scientific or technical character" within the class of protectible subject inatter, a definition that courts interpreted to include architectural plans. Copyright Act of 1909, § 5(i), 35 Stat. 1075, 1077 (1909) (repealed 1976); see also Imperial Homes Corp. v. Lamont, 458 F.2d 895, 898 (5th Cir. 1972); Herman Frankel Org. v. Wolfe, 184 U.S.P.Q. 819 (E.D. Mich. 1974); Herman Frankel Org. v. Tegman, 367 F. Supp. 1051, 1053 (E.D. Mich. 1973); Melville B. NimMER \& DAvid Nimmer, Nimmer ON COPYRIGHT $§ 2.08$ [D] n.162 (1991) [heremafter NIMMER ON COPYRIGHT] and cases cited therein.

The Copyright Act of 1976 protects "pictorial, graphic, and sculptural works," a class that includes "technical drawings, diagrams, and models." 17 U.S.C. $§ 101$. The House Report accompanying the Act hoped to clarify any ambigmities by stating, "An architect's plans and drawings would, of course, be protected by copyright." H.R. REP. No. 1476, 94th Cong., 2d Sess. 55 (1976), reprinted in 1976 U.S.C.C.A.N. 5659, 5668. The Berne Convention Implementation Act of 1988 went further, adding "architectural plans" to the Copyright Act as an explicitly protected class of subject matter. Berne Convention Implementation Act of 1988, Pub. L. No. 100-568 § 4(a)(1)(A), 102 Stat. 2853, 2854 (1988) (amending 17 U.S.C. $\S 101$ ).

51. Conceptually, architectural plans, drawings, and models are easy to fit within the Copyright Act. Such plans are the tangible expression of an idea, and are not excluded from protection because they are "useful articles." Because the only utilitarian function of an architectural plan is to convey information regarding the manner and form in which a building inay be constructed, plans can not be considered a "useful article." Demetriades v. Kaufmann, 680 F. Supp. 658, 664 (S.D.N.Y. 1988); see State Farm Fire \& Cas. Ins. Co. v. White, 777 F. Supp. 952 (N.D. Ga. 1991) (discussing whether insurance policy that covered loss of "tangible property" covered architectural plans). See generally NIMMER ON COPYRIGHT, supra note 50, § 2.08[D] n.164.1 and cases cited therein; David E. Shipley, Copyright Protection for Architectural Works, 37 S.C. L. REv. 393 (1986).

52. See Evans \& Assocs, 785 F.2d at 897 (buildings considered useful articles); see also supra note 24 for a discussion of the separability test and the treatment of useful articles under copyright law.

53. Imperial Homes, 458 F.2d at 899 (copyright in architectural plans does not "clothe their author with the exclusive right to reproduce the dwelling pictured."); Acorn Structures, Inc. v. Swantz, 657 F. Supp. 70, 75 (W.D. Va. 1987) (a building is an "idea" under the Copyright Act of 1976, and is thus unprotectible; construction of a building from unauthorized plans does not constitute copyright infringement), rev'd, Swantz v. American Inst. of Architects, 842 F.2d 1292 (4th Cir. 1988); Tegman, 367 F. Supp. at 1053 ("A person cannot, by copyrighting plans, prevent the building of a house similar to that taught by the copyrighted plans. One does not gain a monopoly on the ideas expressed in the copyrighted inaterial by the act of registering thein for copyright."); see also Scholz Hoines, Inc. v. Maddox, 379 F.2d 84, 86 (6th Cir. 1967); Schuchart \& Assocs. v. Solo Serve Corp., 540 F. Supp. 928, 941 (W.D. Tex. 1982); DeSilva Constr. Corp. v. Herrald, 213 F. Supp. 184, 195-96 (M.D. Fla. 1962); Muller v. Triborough Bridge Auth., 43 F. Supp. 298, 299 (S.D.N.Y. 1942).

These eases centered their reasoning on the idea/expression dichotoiny first enunciated in Baker v. Selden, 101 U.S. 99 (1879), and subsequently rccognized by Congress in $\S 102(b)$ of the Copyright Act. That section provides: 
Although buildings theinselves could not be protected, the separable decorative elements on these structures did qualify for copyright protection. ${ }^{54}$ However, protection of separable decorative elements is relatively ineffective for inost works of inodern architecture, including many of the inost original buildings of our era: During the post-World War II period, modern architectural style increasingly incorporated the utilitarian aspects of a structure as the aesthetic appeal of the building. The funda- . inental tenet of International Style architecture is "form follows function." 55 The separability test leaves little protection to architects and other designers who follow this axioin. ${ }^{56}$ As one coinmentator noted, under the old separability test, "the less exuberant the architecture, the less likely the building would be to ineet the 1976 statute's definition." 57 "Busy" architectural styles such as Beaux-arts likely would receive protection, whereas stark, simple architectural styles such as International Style likely would not.

In no case does copyright protection for an original work of authorship extend to any idea,
procedure, process, system, method of operation, concept, principle, or discovery, regard-
less of the form in which it is described, explained, illustrated, or embodied in such a work.

17 U.S.C. $\$ 102(b)$ (1988). The holder of the copyright in the plans was considered to hold a copyright only in the expression (the plans) of the idea (the concept of a building taking the shape specified), and did not have any copyright in the idea alone. See id. Copying a building by viewing it, or by any means other than actually copying, or using, the plans, therefore only constituted copying an "idea." Reproducing a building by observing, measuring, drawing, or photographing an existing building, without using copyrighted plans, would be classified as non-infringing reverse engineering. Only by copying plans could one copy the expression within which those ideas were embodied. See id. Merely stealing the plans wonld not create a cause of action under copyright, although the copyright holder could still maintain a cause of action against the thief under the state law governing conversion. See infra note $\mathbf{1 3 0}$ and sources cited therein.

54. Because copyright law treated buildings as useful articles, buildings could not receive copyright protection. However, the separability test did allow individual, theoretically detachable decorative elements to seek copyright protection. See supra note 24. Such elements include, for examplc, decorative rehiefs on the side of a building, specific types of pediments or cornices, gargoyles, and original window designs, provided that these elements met the standard of originality. Hearings on the AWCPA, supra note 24, at 61-62. But see Imperial Homes, $458 \mathrm{~F} .2 \mathrm{~d}$ at 899 (copyright in plans did not give architect claim on any features of the structure that those plans detail). Howevcr, architects could not seek copyright in eleinents that were in common use prior to January 1, 1978, the effective date of the Copyright Act of 1976. 17 U.S.C. \$ 301(a) (1988).

55. See William J.R. Curtis, Modern Architecture Since 1900, at 38 (1982).

56. Because the separability test, as currently fonnulated, does not protect the functional elements of a design, those architectural forms whose aesthetic form is nothing but the expression of the functional design of the building would not find protection under the test. For example, many of the most distinctive and original elements of Mies van der Rohe's Seagram Building in New York, such as its exposed structural steel I-beams, would be unprotected.

57. Jane C. Ginsberg, Copyright in the 101st Congress: Commentary on the Visual Artists Rights Act and the Architectural Works Copyright Protection Act of 1990, 14 ColuM.-VLA J.L. \& ARTS 477, 491 (1990); see also Wargo, supra note 15, at $451-54$ (discussing limited usefulness of separability standard). 


\section{B. Congressional Motivation for the Architectural Works Copyright Protection Act}

That copyright law allowed construction of a building as long as plans were not copied was troubling to some. ${ }^{58}$ However, the failure of copyright law to protect coinpleted architectural works did not cause significant problems, as architects and clients successfully used contract law to avoid disputes. ${ }^{59}$ Although the separability test proved difficult to apply to architectural works, such difficulty was shared by all works of applied art. In fact, architects expressed wariness of the effect of copyright protection on their ability to use elements from the work of other architects; ${ }^{60}$ many prominent architects argued against adoption of all or parts of the AWCPA. ${ }^{61}$ Thus the AWCPA was not passed to satisfy a perceived need of the architectural profession. Rather, the impetus for the AWCPA was the perceived treaty requirements arising out of American adherence to the Berne Convention. ${ }^{62}$

During and after the American decision to join the Berne Convention, cominentators debated whether adherence to the Convention required modification of existing domestic copyright law regarding architecture. ${ }^{63}$ The Berne Convention requires, at a minimum, its signatory nations to protect completed architectural works from infringement. ${ }^{64}$ This requirement conflicted with existimg American caselaw

58. See, e.g., Philip J. Infantino, Note, Copyright Wrong: The United States' Failure to Provide Copyright Protection for Works of Architecture, 47 WASH. \& LEE L. REV. 1103 (1990).

59. Rights to use, copy, and reproduce the work of an architect are contractually defined, and generally remain exclusively with the architect. The American Institute of Architects' (AIA) standard form contract grants such exclusive rights to architects. AIA Standard Form Contract, supra note 41 , art. 6.1. These contract rights are not precmpted by the Copyright Act, and have proved successful in ordering the rights between the various parties to an architectural project. See infra note 129. The major drawback of relying on contract law to order rights is that contract provisions only extend to parties in privity. Third parties remain unaffected by an allocation of rights in a contract.

60. Hearings on the AWCPA, supra note 24, at 111, 115-16 (testimony and prepared statement of David Daileda on behalf of the AIA) ("Our concern is that the well-accepted traditions of reference and limited borrowing of elennents and details should not be suppressed.").

61. Id. at 14, 20-23 (statement of architect Michael Graves); id. at 110-12 (statement of David Daileda, on behalf of the AIA).

62. As with most intellectual property legislation over the past two decades, the driving force behind the legislation was Representative Robert W. Kastenmeier, Chairman of the House Subcommittec on Courts, Intellectual Property and the Administration of Justice. See generally Syinposium, Copyright and Legislation: The Kastenmeier Years, LAw \& CONTEMP. ProBs., Spring 1992, at 3.

63. See, e.g., Bucher, supra note 46; Infantino, supra note 58; Wargo, supra note 15.

64. Article 2(1) of the Paris text of the Berne Convention requires member nations to extend copyright protection to "works of . . . architecture; illustrations, . . plans, sketches and threcdimensional works relative to ... architecture." Berne Convention, supra note 18. The fact that the text of the treaty distimguishes "architeetural works" from plans and models indicates that "architeetural works" include the completed architectural work. Were it otherwise, "architectural works" 
establishing that American copyriglit extended only to architectural plans, and not to completed architectural works. ${ }^{65}$ Adlierence to the Convention - even under the United States' intended "minimalist" approach to adherence ${ }^{66}$-would require the addition of completed architectural works to the categories of protected subject matter under American copyright law. ${ }^{67}$

\section{C. "Architectural Work" and "Building" Defined}

Section 703 of the AWCPA provides that "architectural works" be added to the list of "works of authorship" enunerated in section 102 of the Copyright Act. To avoid the interpretive difficulties that are the necessary companion of section 102's use of conceptually broad terms, Congress carefully defined the term "architectural works" in section 101:

An "architectural work" is the design of a building as embodied in any tangible inedium of expression, including a building, architectural

would be bereft of meaning. The periodic interpretive guidelines to the Berne Convention promulgated by the World Intellectual Property Organization (WIPO) are similarly unambiguous that completed architectural works are protected by the treaty. WORLD INTELLECTUAL PROPERTY Organization, Guide to the Berne Convention for the Protection of Literary and ARTISTIC Works (PARIS ACT, 1971) 16 (1978).

Beyond this minimum requirement for protection, the Berne Convention allows wide latitude in both the subject inatter protected and in the scope of protection offered. Wargo, supra note 15, at 415-39. The various member nations of the Berne Convention have taken disparate approaches in enforcernent and application of the architectural copyright provisions. Id.

65. See supra notes 49-57.

66. Wargo, supra note 15 , at 407 n.18-19.

67. Some commentators have disputed that the Berne Convention requires protection of completed architectural works. See Berne Convention Implementation Act of 1987: Hearings on H.R. 1623 Before the Subcomm. on Courts, Civil Liberties, and the Administration of Justice of the House Comm. on the Judiciary, 100th Cong., 1st \& 2nd Sess. 689, 693 (1988) (testimony of Barbara Ringer, former Register of Copyrights); id. at 667 (testimony of Paul Goldstein, Professor of Law, Stanford University); Bucher, supra note 46, at 667 . However, a brief examination of the history of the architecture provisions of the Berne Convention reinoves any doubt that the treaty mandates protection for coinpleted architectural works. Although the inember nations of the Berne Convention resisted at first, the Berne Convention has protected architectural works as early as the 1908 Berlin Revision. RICKETSON, supra note 15, at 146, 229. Like the United States, the siguatory nations of the Berne Convention were slow to accept the copyrightability of architecture. Following the 1908 revision, all of the Berne inember nations, with the exception of Norway, enacted legislation giving completed architectural works copyright protection. Id. at 256; Wargo, supra note 15, at 413. The subject matter provisions goverming architecture remained fundamentally unchanged through the revisions of the Treaty in 1948 and 1971.

Given the facial clarity of the Berne Convention, it inight at first seem puzzling that during the Congressional debates on the American decision to adhere to the Convention, some critics stated that it did not require copyright protection for completed architectural works. However, the signatory nations of the Convention take widely disparate approaches to enforcing the provisions of the treaty, and have never had uuiform laws regulating the copyrightability of architecture. These different approaches may have confused the issue for these commentators. More thorough histories of the Berne Convention are included in Ricketson, supra note 15, and in Wargo, supra note 15, at 409-14. 
plans, or drawings. The work includes the overall form as well as the arrangement and compositiou of spaces and elements in the design, but does not include individual standard features. ${ }^{68}$

Under this definition, the AWCPA protects only the design of "buildings." However, many architectural works are not "buildings." The original version of the AWCPA, H.R. 3990, protected not only buildings, but also other "three-dimensional structures." 69 This proposed category would have included "cases where architectural works [are] embodied in innovative structures that defy easy classification."70 The House Subcommittee chose to delete this' phrase from the final version of the bill, reasoining that the phrase would extend protection to "interstate highway bridges, cloverleafs, canals, dams, and pedestrian walkways," none of which the Subcommittee felt were worthy of copyright protection..$^{71}$ On the other hand, a limitation to "buildings" seems to leave out a great many structures normally considered to be works of architecture. Architecture critic Paul Goldberger has stated that the two greatest works of architecture in New York City are Central Park and the Brooklyn Bridge, ${ }^{72}$ neither of which would receive protection under the AWCPA. Golf courses, gardens, tunnels, bridges, overpasses, fences, and walls are only a few of the structures designed by architects that would not fit the common definition of "building." Unless courts interpreting the AWCPA contort the definition of "building" well beyond its generally accepted limits, architects designing these other structures will not find copyright protection under the new subject matter category for architectural works. ${ }^{73}$

Congress intended that the term "building" have a broad meaning to compensate for the exclusion of "other three-dinnensional structures" from the scope of the AWCPA. The drafters therefore explicitly stated that the term "building" was not to be limited to structures inhabited by

68. Architectural Works Copyright Protection Act, Pub. L. No. 101-650, § 702(a), 104 Stat. 5133, 5133 (1990) (amending 17 U.S.C. § 101).

A work need not be designed by an architect in order to be considered a work of architecture. Copyright law looks to the character of the work created, and not to the status of the author of that work, in determining the appropriate subject matter category. Engineers, unlicensed architects, or laymen can all qualify as "authors" of a copyrightable building. See Hearings on the AWCPA, supra note 24, at 73 n.35 (statement of Ralph Oman, Register of Copyrights).

69. H.R. 3990, 101st Cong., 2d Sess. § 2(a) (1990), reprinted in Hearings on the AWCPA, supra note 24 , at 3,4 .

70. H.R. REP. No. 735, 101st Cong., 2d Sess. $19-20$ (1990), reprinted in 1990 U.S.C.C.A.N. 6935, 6950-51.

71. Id.

72. Paul Goldberger, The City Observed: New York 27 (1979).

73. These works will have to seck protection under 17 U.S.C. $\S 102(a)(5)$ as "pictorial, graphic [or] sculptural works." However, in order to qualify for protection as a $\S 102(a)(5)$ "sculptural work," a work must satisfy the separability test for utilitarian objects. See supra note 24. 
humans. ${ }^{74}$ Rather, the term was also to cover "structures that are used, but not inhabited, by human beings, such as churches, pergolas, gazebos, and garden pavilions."75 The legislative history provides few clues for defining the line between protected "buildings" and unprotected "other three-dimensional structures." This Note proposes that two categories of completed architectural works be excluded from the definition of "architectural work." First, structures whose form is dictated by engineering considerations should be excluded. Second, works such as gardens and parks, that are not enclosed structures, but rather organizations of space, should also be excluded.

Protection of the first category of works would be mconsistent with the goals of copyright law. The works identified by Congress as unprotectible — bridges, dams, canals, walkways, and similar works-are works whose overall forms are generally dictated by engineering considerations. In this respect, the form of these structures do not embody the creative expression of an author. These designs merely express the laws of physics and structural engineering apphed to a certain context.

Congress accepted architect Michael Graves's descriptive terins for two types of architectural language: "internal" and "poetic." "Internal" language consists of those elements that are dictated and "determined by praginatic, constructional, and technical requirements." "76 As such, these elements cannot express the creative mind of the architect. "Poetic" langnage, on the other hand, is "'responsive to issues external to the building, and mcorporates the three-dimensional expression of the myths and rituals of society." "77 The structures seen by Congress as unprotectible are all defined by what Graves described as "internal" language. Congress intended the AWCPA to protect only what Graves described as "poetic" language. ${ }^{78}$

Permitting copyright in designs not dictated by praginatic concerns, but not protectimg the functionally dictated designs, is renniniscent of the tests used to define functionality im trademark cases. Under trademark law, a design is considered de jure functional if it is "the best or one of a few superior designs available."79 When an architect has little choice in a

74. H.R. REP. No. 735, supra note 70, at 20, reprinted in 1990 U.S.C.C.A.N. at 6951.

75. Id.

76. Id. at 18-19, reprinted in 1990 U.S.C.C.A.N. at $6949-50$ (quoting statement of architect Michael Graves).

77. Id.

78. Id. The legislative history further states, " [T] $]$ echnology is not art .... The key to the art of architecture is the conviction and sensitivity with which technology and function are interpreted aesthetically, in solutions of a practical social purpose.' "Id. at 18, reprinted in 1990 U.S.C.C.A.N. at 6949 (quoting ADA L. HUXTABLE, ARCHITECTURE ANYONE? (1986)) (alteration in original).

79. In re Morton-Norwich Prods., Inc., 671 F.2d 1332, 1341 (C.C.P.A. 1982). 
design, and when that design is dictated not by the architect's artistic mind but instead by the laws of physics or some contextual necessity, courts consider that design functional for trademark purposes. This test views artistic expression as lying in the choice the artist makes from among equally functional options in solving a design problem. Although it may perform some function, a design qualifies as copyrightable expression if it represents such a choice. 80

Organizations of space, such as gardens, parks, and golf courses, comprise the second category of works that should not be protected by the AWCPA. Works that are not enclosed by any structure, although perhaps requiring much time, effort, and expense for an architect to prepare, and having a large potential for copying, simply cannot be considered buildings. Barring a revision in the definition of architectural works in section 101, only a distorted application of "building" will protect these works. ${ }^{81}$

If a work does qualify as a "building," it may also qualify as a section 102(a)(5) "sculpture." Prior to passage of the AWCPA, monumental, nonfunctional works of architecture received protection under section 102(a)(5) as "sculptural works." 82 This provision remains unaffected by the AWCPA. Works such as the Statue of Liberty, the Washington Monument, and the Gateway Arch continue to receive section 102(a)(5) protection as sculptural works. As a result, the AWCPA offers dual protection to such works, as Congress intended such nonfunctional works to be within the definition of both section 102(a)(5) "sculptural works" and section 102(a)(8) "architectural works."83

What the AWCPA does not protect, however, are some of the most profitable works produced by architects. Over the past twenty years, architects have used their skills to design a wide variety of household itenns. Teapots, electric razors, telephones, and other items have all received a great deal of attention from architects. ${ }^{84}$ For an entire generation of Americans, these architect-designed iteins have becoine totems of success. ${ }^{85}$ Their designers have blurred the line between architecture, art,

80. This approach is consistent with the general structure of our intellectual property laws. Patent law, not copyright, is the province of designers who create more efficient approaches to enginecring questions. The most efficient solutions to pragmatic problems should be removed from the palette of elements available to designers only under the more stringent requirements of patent law. See discussion of patent law infra notes $100-09$ and accompanying text.

81. However, the plans for such works could be copyrighted.

82. H.R. REP. No. 735 , supra note 70, at 20 n.43, reprinted in 1990 U.S.C.C.A.N. at 6951 n.43.

83. Id. at 20, reprinted in 1990 U.S.C.C.A.N. at 6951.

84. For example, architects Michael Graves and Alvar Aalto have designed, respectively, nowfamous teapots and vases. Bruce Handy, Yuppie Porn, SPY, Dec. 1987, at 60.

85. Id. 
and industrial design. However, these objects, though designed by prominent architects, will not qualify as section 102(a)(8) architectural works, and must instead qualify as section 102(a)(5) sculptural works. ${ }^{86}$ As in all copyright law, it is the nature of the work, and not the profession of the author, that determines the copyrightability of the work.

\section{D. "Original" and "Not Wholly Functional" Designs}

To be protected under the AWCPA, a structure must first qualify as a "building"; it must then satisfy a two-part test to establish that its design is first, original, and second, not wholly functional. As stated by the House:

A two-step analysis is envisioned. First, an architectural work should be examined to determine whether there are original design elements present, including overall shape and interior architecture. If such design elements are present, a second step is reached to examine whether the design elements are functionally required. If the design elements are not functionally required, the work is protectible without regard to physical or conceptual separability. As a consequence, contrary to the Committee's report accompanying the 1976 Copyright Act with respect to industrial products, the aesthetically pleasing overall shape of an architectural work could be protected under this bill. ${ }^{87}$

Defining originality stands as one of the major interpretive difficulties underlying the AWCPA. In order to fulfill legislative intent and the purposes of copyright law, the standard for originality should be very modest. The legislative history states explicitly that "the proposed legislation incorporates the general standards of originality applicable for all other copyrightable subject matter. This standard does not include requirements of novelty, ingenuity, or aesthetic merit."88 Moreover, one of the oldest and most fundamental principles of American copyright law is that originality shall not be conditioned on a judicial evaluation of artistic worth. ${ }^{89}$ For AWCPA purposes, originality can take inany forms: the use of unoriginal individual elements in original ways, the coinbination of new elements with old eleinents, and the placeinent of the otherwise banal into new and original contexts. As the drafters of the AWCPA stated in the legislative history:

The phrase "arrangement and composition of spaces and elements" recognizes that: (1) creativity in architecture frequently takes the form of a selection, coordination, or arrangement of unprotectible elements note 24.

86. Sculptural works, unlike architectural works, are subject to the separability test. See supra

87. H.R. REP. No. 735, supra note 70, at 20-21, reprinted in 1990 U.S.C.C.A.N. at 6951-52.

88. Id. at 21 , reprinted in 1990 U.S.C.C.A.N. at 6952.

89. See Bleistein v. Donaldson Lithographing Co., 188 U.S. 239, 251 (1903); Tennessee Fabricating Co. v. Moultrie Mfg. Co., 421 F.2d 279 (5th Cir.), cert denied, 398 U.S. 928 (1970). 
into an original, protectible whole; (2) an architect inay incorporate new, protectible design eleinents into otherwise standard, unprotectible

building features; and (3) interior architecture inay be protected. ${ }^{90}$

This broad definition of architectural design comports with the conception of architecture, discussed earlier, as a combination of disparate elements. ${ }^{91}$ The drafters seem to have contemplated that the originality and the artistic impact of a work cannot be evaluated outside of the context in which that work appears. ${ }^{92}$

Demonstratimg nonfunctionality may be even more problematic. As stated above, in recent years application of the separability test has plagned attempts to define objects as either functional or nonfunctional. ${ }^{93}$ Although Congress intended to avoid applying the separability test to arclitectural works, ${ }^{94}$ this two-step analysis for AWCPA protection could conceivably be imterpreted to revive the separability test.

A narrow interpretation of "functionally required" best serves the purposes of copyright law and the architectural profession. Elements of an architect's design that are not dictated by functional considerations can be used to express the architect's creativity. If these elements are used in a particularly aesthetically or commercially pleasing way, the architect should be given the opportunity to profit from reuse of that particular combination of elements.

\section{E. Individual Design Elements}

Although the AWCPA protects an overall design of an architectural work, the Act does not protect the individual standard features used in that work. ${ }^{95}$ The drafters believed that "[a] grant of exclusive rights in such features [such as common windows, doors, and other staple building components] would impede, rather than promote, the progress of architectural mnovation."96 Copyriglit protection is inappropriate for

90. H.R. REP. No. 735, supra note 70, at 18, reprinted in 1990 U.S.C.C.A.N. at 6949.

91. See supra Part I(B).

92. See Stanley ABERCROMBIE, ARChitecture AS ART 87-97 (1984) (“Architecture never exists in a vacuum; it is touched on all sides by its context.").

93. See supra note 24.

94. H.R. REP. No. 735, supra note 70, at 20, reprinted in 1990 U.S.C.C.A.N. at 6951.

95. "An 'architectural work' . . . includes the overall form as well as the arrangement and composition of spaces and elements in the design, but does not include individual standard features." AWCPA $\S 702$ (a), 17 U.S.C.A. $\$ 101$ (West Supp. 1992) (emphasis added).

96. H.R. REP. No. 735, supra note 70, at 18, reprinted in 1990 U.S.C.C.A.N. at 6949.

For example, the John Hancock Building in Chicago could be protected, but the X-shaped steel beams that rise along its side would not be protected, because they are functionally determined. Frank Lloyd Wright could have sought copyright protection for his Fallingwater house, but this copyright would not extend to the functionally determined elements such as the cantilevered terrace. Interpretive problems may develop in determining exactly when a feature is protected and when it is not protected. Congress intended that functionality have a narrow reach. 
these individual design elements. Architects must be allowed to experiment with recombining individual features in new and creative ways.

As explained above in Part $I(B)$, architectural design consists of the rearrangement of individual elements of the architectural "vocabulary." Architectural creativity and progress are served by inaking these individual elements freely available for use and adaptation by others. A door, window, or roof design can be transformed into an original form by placing it im a different context, or by recombining it with different elements. Preventing architects froin reusing these eleinents would be analogous to depriving authors of the use of standard "stock characters" in their novels or screenplays, ${ }^{97}$ or to depriving these same authors of the use of standard plot lines in their works. ${ }^{98}$ Because alınost all of the design elements in an architectural work serve soine functional purpose, a broad definition of "functionally required" will preclude vast portions of architectural works froin enjoying protection. If courts define "functionally required" broadly, the AWCPA will take on a very limited scope. However, it should be remembered that the test envisioned by Congress is that a design element inust be functionally required in order to disqualify an architectural work froin protection. As stated above, the conception of functionality anticipated by Congress is quite narrow, and recalls the test used in trademark law. ${ }^{99}$ If a design element is merely one of many

97. See generally Dean P. DeNiro, Protecting Characters Through Copyright Law: Paving a New Road upon Which Literary, Graphic and Motion Picture Characters Can All Travel, 41 DePAUL L. REv. 359 (1992); Michael T. Helfand, Note, When Mickey Mouse Is as Strong as Superman: The Convergence of Intellectual Property Laws to Protect Fictional Literary and Pictorial Characters, 44 STAN. L. Rev. 623 (1992).

98. Two recent examples of the use of standard plot lines come quickly to mind. The first is the recent glut of "body-switching" movies, in which an older character temporarily inhabits the body of a younger character. See, e.g., 18 AgAIN (New World Pictures 1988); ALL OF ME (Universal 1984); Big (20th Century-Fox 1988); LIKE FATHER, LIKe Son (Tri-Star Pictures 1987); VICE VERSA (Columbia Pictures 1988). These films all added something new to the art form, even though they were based on the same plot structure, derived from previous forms, such as Freaky Friday, and may even have a common genesis in plots first established in The Prince and the Pauper.

The second is the seemingly ubiquitous motion picture plot line featuring two initially incompatible and very different characters who are placed into a situation in which they are forced to cooperate. Invariably, the characters become best friends, and learn something about themselves in the process. See, e.g., 48 Hours (Paramount Pictures 1982); Lethal WeApon (Warner Bros. 1987); Midnight RUN (Umiversal Pictures 1988). The similarities in this type of film can be truly striking. For example, in both Twins and Rain Man, the main character discovered a long-lost brother. The mam character initially dislikes his new-found brother, and is forced into a crosscountry car ride. On their ride across country, the two learn to look beyond their differences and forge a close relationship. RAIN MAN (United Artists 1988); TwINS (Universal Pictures 1988).

99. See supra notes 79-80 and accompanying text. It also recalls the approach of the district court in East/West Venture v. Wurmfield Assocs., 722 F. Supp. 1064 (S.D.N.Y. 1989). In East/ West, the court addressed a claim that a building's design was dictated by the configuration of the property on which it stood, by the presence and location of preexisting structures on the property, and by economic and zoning constraints. The court asked whether, "if a property is of such a unique 
equally useful elements that might have been chosen, then there seems little reason to categorize such elements as functionally "required."

Although separable elements do not receive protection under section 102(a)(8), designers of such elements are not without protection. The separable decorative elements of an architectural work may still qualify for protection under section 102(a)(5) as "sculptural works." Additionally, a designer of separate elements may instead choose to seek patent protection for those separate elements.

The subject matter covered by patent law overlaps much of the subject matter of copyright and federal trademark law. ${ }^{100}$ Like copyright law, American patent law is constitutionally grounded in the purpose of promotimg progress im "science and the useful arts." Despite this common genesis, patent law differs greatly from copyright and trademark law in substance. The limited scope of patent law, ${ }^{101}$ its narrow protection, ${ }^{102}$ and its shorter term ${ }^{103}$ all reflect its subject matter. Unlike copyrighted objects, patented objects are generally more adaptable for use im other forms; more imiportant, allowing others to tinker with, adapt, and use patented objects im new ways advances the arts and sciences. Consequently, the law makes it harder for these articles to qualify for protection, and those articles that do qualify for protection receive only shorter and more limited protection.

Patent law recognizes two types of patents: "utility" and "design" patents. ${ }^{104}$ Design patents contain significant overlap with copyright and

nature that its plans relating to development scheme and basic design features must be substantially identical, ... the first architect to design plans [has] a right to prevent the use of plans incorporating such scheme and features." The court held that an architect can only show infringement if "something unique in the plans not demanded by the uniqueness of the site inust be copied." Id. at 1068 .

100. The subject matter of patent law includes "processes," "machines," "manufactures," and "compositions of matter." 35 U.S.C. $§ 101$ (1988). Thesc categories can include a completed architectural work, separate elements of that work, and the processes and methods used in construction of similar works. Louis Altman, Intellectual Property Law and the Construction Industry, Part I, $70 \mathrm{~J}$. PAT. \& Trademark OFF. SOC'y 491, 491-99 (1988).

101. The rights and remedies available to patent holders also differ from those available through copyright or trademark. Patent law confers only the rights to "make, use, or sell" a design, distinct from the right to copy or otherwise reproduce a work conferred by copyright. 35 U.S.C. $\S 103$.

102. To be eligible for patent protection, an object must be "novel," $i d$. $\S 102(a)$, and its design must have been "non-obvious to one of ordinary skill in the relevant craft." Id. $\S 103$. The novelty requirement creates an absolute monopoly. If a second architect creates a design independent of a prior patent holder's identical design, the second inventor would be liable for patent, bnt not copyright, infringement. While the novelty requirement serves to grant broader protection than would be available under copyright, the patent requirement of non-obviousness makes a patent harder to qualify for than a copyright.

103. A design patent runs only for a term of fourteen years. Id. $\S 173$. Non-design patents run for a term of seventeen years. Id. $\S 154$.

104. Utility patents are issued for objects and processes with a utilitarian function. Design patents, in contrast, are issued for ornamental designs for articles of manufacture. Bonito Boats, Inc. v. 
trademark law. Like utility patents, the subject of a design patent must be novel, ${ }^{105}$ original, ${ }^{106}$ and non-obvious to a person of ordinary skill in the art. ${ }^{107}$ Unlike utility patents, design patents must not serve a primarily functional or utilitarian purpose. ${ }^{108}$ Design patent protection of "ornamental" works provides the necessary protection for the individual elements of architectural design. ${ }^{109}$

\section{F. Architectural Works Distinguished from Architectural Plans}

For the sake of clarity, the drafters' definition of an "architectural work" explicitly included works embodied in "architectural plans, or drawings." 110 Thus an architectural work need not be constructed in order to receive protection. "[A] work of architecture may be embodied in the built design - the constructed three-dimensional building -or in plans, drawings, or in 'any tangible medium of expression,' such as a blueprint or a computer disk." 11 The original version of the bill referred

Thunder Craft Boats, Inc., 489 U.S. 141, 147-48 (1989). Architects would be likely to seek a utility patent for innovative processes, methods of construction, or utilitarian advances. New materials used in the construction of architectural works unambiguously fit within the patentable category of compositions of matter. New types of steel and concrete can be patented, as can new non-structural materials such as glass or carpeting. Tools, machines, and other mechanical implements used in the construction of architectural works are patentable as "machines." Similarly, "processes" include innovative methods of constructing architectural works. See generally Altman, supra note 100, at 491-501.

10S. 35 U.S.C. $\$ 102$.

106. Id.

107. Id. $\S 103$.

108. Id. § 171; Power Controls Corp. v. Hybrinetics, Inc., 806 F.2d 234, 238 (Fed. Cir. 1986); Barofsky v. General Elee. Corp., 396 F.2d 340, 342 (9th Cir. 1968), cert. denied, 393 U.S. 1031 (1969).

109. Soine examples of separable elements of architectural works that have qualified for design patent proteetion are lighting fixtures, Day-Brite Lighting, Inc. v. Sandee Mfg. Co., 126 U.S.P.Q. 32 (N.D. Ill. 1960) (holding patent valid and infringed), rev'd, 286 F.2d 596 (7th Cir.) (holding patent invalid on prior art grounds), cert. denied., 366 U.S. 963 (1961); handrailings, Blumeraft of Pittsburgh v. Citizens \& S. Nat'1 Bank, 286 F. Supp. 448 (D.S.C. 1968) (holding patent valid and infringed), rev'd, 407 F.2d 557 (4th Cir.) (holding patent invalid on prior art grounds), cert. denied, 395 U.S. 961 (1969); patterned floor tiles, In re Bartlett, 300 F.2d 942 (C.C.P.A. 1962); and settings of plate glass in store fronts, Kawneer Co. v. Pittsburgh Plate Glass Co., 109 F. Supp. 228 (W.D. Mich. 1952) (holding patent invalid on prior art grounds). In addition, entire buildings can qualify for patent protection, provided they meet the statutory requirements of novelty, originality, and nonobviousness. See Altman, supra note 100, at 497-98.

110. AWCPA § 702(a), 17 U.S.C.A. § 101 (West Supp. 1992); see also H.R. REP. No. 735, supra note 70, at 19, reprinted in 1990 U.S.C.C.A.N. at 6950.

111. H.R. REP. No. 735, supra note 70, at 19, reprinted in 1990 U.S.C.C.A.N. at 6950 (emphasis added). As long as the idea for the building has been embodied in some tangible medium of expression, such as plans or drawings, an unconstructed architectural work is protectible under 17 U.S.C. $\S 106(a)(8)$. For a pre-AWCPA case that discusses the point at which infringement is implicated, see East/West Venture v. Wurmfield Assocs., 722 F. Supp. 1064 (S.D.N.Y. 1989). Requiring that a building be built before infringement is implicated would be to find infringement only at the point at which economic waste would become great enough to militate against many forms of relief. 
only to architectural work "as einbodied in" buildings. 112 To avoid any potential ambiguity, the drafters clarified the scope of protected subject matter by including "plans" within the definition. However, it should be noted that this exphicit enumeration was unnecessary. Prior to the enactment of the AWCPA, section 102(a)(5) of the Copyright Act of 1976 protected architectural plans, drawings, and inodels. ${ }^{113}$ In no way did Congress intend the AWCPA to subsume any of the protections offered by section $102(a)(5) .{ }^{114}$ As a result, an architect possesses two separate copyrights for a completed architectural work: a copyright in the constructed building as defined in section 102(a)(8), and a copyright in the plans and drawings, protected within section 102(a)(5). "The bill's intention is to keep these two forms of protection separate. ... Either or both of these copyrights may be infrimged and ehgible separately for damages." 115 Claims of infringement may be made regardless of whether the infringer gained access through copymg the completed work or copying the plans. ${ }^{116}$

Allowing inultiple forms of rehef, as the AWCPA does, is a necessary concomitant of the idea/expression dichotoiny upon which American copyright law is based. The same idea inay be expressed in several media, each of which is separately ehgible for copyright protection. ${ }^{117} \mathrm{~A}$ copyright holder may enjoy greater success in proving the access eleinent of an infringement action based on infringement of the completed work, as opposed to infringement of the plans. ${ }^{118}$ As a matter of proof, it will

112. H.R. 3990, supra note $69, \S 2(\mathrm{a})$, reprinted in Hearings on the AWPCA, supra note 24 at 4.

113. 17 U.S.C. $\$ \S 101,102(a)(5)$ (1988); see supra Part II(A).

114. "Protection for architectural plans, drawings, and models as pictorial, graphic or sculptural works under section 102(a)(5), title 17, Umited States Code, is unaffected by this bill." H.R. REP. No. 735, supra note 70, at 19, reprinted in 1990 U.S.C.C.A.N. at 6950.

115. Id.

116. A copyright holder may prefer to bring a claim under $\S 102(\mathrm{a})(8)$, because access might be easier to establish. See infra note 118. Copyright law relies on the concept of "access" to establish infringement. As the Register of Copyrights stated at the Subcommittee Hearings, and as has developed in the caselaw, where a three-dimensional work mects the standard for protection, infringement may lie regardless of whether access to the three-dimensional work is obtained from a two-dimensional or three-dimensional depiction thereof. Hearings on the AWCPA, supra note 24, at 67-68; H.R. REP. No. 735, supra note 70, at 19, reprinted in 1990 U.S.C.C.A.N. at 6950.

117. For example, a song is eligible for a copyright in both the actual sound recording, 17 U.S.C. $\S 102(a)(7)$ (1988), and in the underlying musical composition, id. $\S 102(a)(2)$.

118. A copyright infringement action requires proof of two elements: ownership of a valid copyright by the plaintiff and copying, by the defendant, of constituent elements of the work that are original. Feist Publications v. Rural Tel. Serv., 111 S. Ct. 1282, 1296 (1991). As actual copying by the defendant is difficult to prove, courts rely on the concepts of access and substantial similarity to impute copying. In most cases, a plaintiff must prove both access to and substantial similarity with the copyrighted work. However, courts have found copying to have occurred even without access if the similarity between the works is so striking and substantial as to preclude the possibility of independent creation of the work by the defendant. NIMMER ON COPYRIGHT, supra note 50, $\S 13.02[\mathrm{~B}]$; see id. $\S 13.02[\mathrm{~B}]$ n.20 (citing cases in which courts found copying without access); id. 
generally be easier to demonstrate access to a completed structure or a work in progress than to prove access to plans. The completed structure will usually be visible to the public, whiereas plans will not generally be accessible. ${ }^{119}$ If a copyright holder prevails on claims of infringement of both the completed work and the plans, reduction of an award of damages would prevent a wimdfall of double renumeration. ${ }^{120}$

\section{SCOPE of Protection AND Relief UNDER the Act}

The inost striking aspect of tlie AWCPA is the limited scope of the protection it affords to architectural works. Responding to pragmatic concerns, Congress cliose to deprive architectural works of protections offered to other copyriglitable works. Holders of copyriglits in architectural works can neitlier prevent alteration and destruction of tleir works, nor prevent the production of two-dimensional pictorial copies of the work. Congress correctly viewed alteration and destruction of a building by its owner to be practical necessities. However, allowing the production of pictorial copies of tlie work may prove to be an overbroad provision that deprives an architect of a potentially valuable right in derivative works.

\section{A. Alteration and Destruction of Architectural Works}

Only four of the five exclusive riglits granted under section 106 of the Copyriglit Act of 1976 inake sense whien applied to arclitecture: the riglit to transform or adapt the work into anotlier form"121 ("tlie derivative works riglit"); the riglit to make copies of the protected work ${ }^{122}$ ("tlie right of reproduction"); the riglit to distribute copies of the protected work to the public 123 ("tlie distribution right"); and the right to display the work publicly ${ }^{124}$ ("tlie display riglit").

$\$ 13.01[B]$ n.27 (citing cases in which courts found direct evidence of copying); see also Alan Latunan, "Probative Similarity" as Proof of Copying: Toward Dispelling Some Myths in Copyright Infringement, 90 COLUM. L. REv. 1187, 1194-95 (1990) (discussing elements of proof in copyright infringement cases).

119. It should be noted that a plaintiff may not even have to prove actual access. See NimMER ON COPYRIGHT, supra note 50, §13.02[A]. However, courts are wary of finding infringement based on this "double circuunstantial evidence" of copying. Id.; see Morse v. Fields, 127 F. Supp. 63 (S.D.N.Y. 1954) (despite striking similarities between works, court refused to find that copying of magazine article occurred absent a showing of access).

120. H.R. REP. No. 735, supra note 70, at 19, reprinted in 1990 U.S.C.C.A.N. at 6950.

121. 17 U.S.C. $\$ 106(2)$ (1988).

122. Id. \& 106(1).

123. Id. \& 106(3).

124. Id. $\S 106(5)$. The Copyright Act grants holders of copyrights in musical and dramatic works the additional exclusive right to perform the work publicly. Id. $\S 106(4)$. However, this right has no application to architectural works. 
The AWCPA severely limits the copyright holder's derivative works right. AWCPA section 704(a) adds a new section, section 120(b), to the Copyright Act:

ALterations to AND Destruction of BUILDINGS-Notwithstanding the provisions of section 106(2), the owners of a building einbodying an architectural work inay, without the conseut of the author or copyright owner of the architectural work, make or authorize the making of alterations to such building, and destroy or authorize destruction of such building. 125

Congress viewed this limitation as a practical necessity. In order to perform its utilitarian functions, a building inust be able to adapt and change. Conditioning changes on the approval of the original architect may lead to frustrating delays.

The original draft of the AWCPA had allowed a building owner to Inake only "minor" or "necessary" changes without first receiving the permission of the architect. ${ }^{126}$ However, at the urging of architect Michael Graves, Congress expanded the owner's right to include the right to inake any changes to the structure for any reason, and to include the right to order the destruction of the building. Congress accepted Graves's arguinent that if the architect retained the right to approve changes to the structure, building owners would deinand that architects assigu their copyright in the structure over to the owner. ${ }^{127}$ In this respect, the AWCPA demonstrated the necessity of soliciting the active participation of affected professionals in drafting legislation in the often arcane realm of intellectual property.

It should be noted that under the AWCPA, an architect who feels strongly that he must retain the right to approve alterations in his work may still reserve that right as a matter of contract law. ${ }^{128}$ Contract

The display right may prove important when apphied to architectural plans. Because the AWCPA includes architectural plans within the definition of architectural work, the copyright holder of architectural plans, and not the building owner, will have the exclusive right to display the architectural plans at museums, on the premises of the building, or in other public places. But see Hearings on the AWCPA, supra note 24, at 69 (statement of Ralph Oman, Register of Copyrights) (claiming that architecture should not have display right). In the event that a building owner wishes to display the plans to the building, or make some use of the plans for any reason other than constructing the building, the building owner should retain an express assignment of this right from the architect in their contract.

125. 17 U.S.C.A. $§ 120(b)$ (West Supp. 1992).

126. See H.R. 3990, supra note 69, § 4(a), reprinted in Hearings on the AWPCA, supra note 24, at 3, 5-6.

127. Hearings on the AWCPA, supra note 24, at 16 (statement of architect Michael Graves).

128. State law claims of conversion, misappropriation, and unjust enrichment also remain available to architects. 
claims will continue to play an important role in regulating rights between architects, chents, and others, and are not preeinpted by the Copyright Act. ${ }^{129}$ In fact, it is chiefly due to the effectiveness of the parties in ordering their rights through enforceable contracts that copyright claims regarding architectural works have not arisen frequently in federal court. ${ }^{130}$

In addition, local landinark and historic preservation laws will protect a work whose aesthetic appearance is considered too valuable to alter. Local landmark and historic preservation laws are an often overlooked, but increasingly important, legal protection for architectural works. These laws will help inake up for the AWCPA's failure to prevent alteration or modification of the buildings thought by the local community to be of the most aesthetic or historic worth. The AWCPA explicitly upholds such local laws, stating that the Copyright Act shall not preempt "[s]tate and local landmarks, historic preservation, zoning, or building codes, relating to architectural works protected under [17 U.S.C.] section 102(a)(8)."131 As a practical inatter, this means that state law will continue to play an important role in regulating the construction, modification, and destruction of architectural works.

Respect for local landmark laws is founded on principles of federalism. Questions of how and when to construct or destroy buildings are questions of local concern. Similarly, questions of which buildings are considered aesthetically or historically worthy of preservation are questions that a local governing board is far better qualified to answer than federal officials or federal judges. Aesthetic merit is intrinsically contextual. A particular building inay have extraordinary inerit in one settimg that it would lack in another setting. Permitting the use of federal statutes to prevent destruction or modification of buildings would distort the purposes of copyright law, and infringe on valid local concerns. The Copyright Act, the Lanham Act, and the Patent Act are not federally created norns of artistic inerit, and are not based on the inoral rights of

129. The Copyright Act preempts only those state law rights that are "equivalent to copyright." 17 U.S.C. $\S 301(b)$ (1988). Defining the boundaries of equivalency to copyright has proven problematic. See Donald Frederick Evans \& Assocs. v. Continental Homes, Inc., 785 F.2d 897, 913-15 (11th Cir. 1986); NIMMER ON COPYRIGHT, supra note 50, § 1.01[B][1];

130. See Hardin \& Choy, Inc. v. Autumn Shelter, Inc., 1988 WL 156,273 (N.D. Cal. Dec. 7, 1988) (granting summary judgment motion on copyright infringement and conversion claims because contract provision allowed purchasers of plans to transfer any rights in plans to third parties); Whitney, Atwood, Norcross Assocs. v. Architeet's Collaborative Inc., 18 U.S.P.Q.2d 1243 (D. Mass. Jan. 4, 1991) (ambiguously worded contract provision governing copyright ownership of architectural plans preeludes Rule 12(b)(7) motion to dismiss).

131. AWCPA $\S 705,17$ U.S.C.A. $§ 301(b)(2)$, (4) (West Supp. 1992). 
an author. Federal protection of architectural works can only be countenanced if that protection will serve the societal goals identified in the Constitution: to encourage creativity in the useful arts (for copyright and patent law) and to regulate interstate commerce (for tradeinark law). Claims that an architectural work inust be protected based on the intrinsic worth of that work and its value to the local community, are not relevant to federal intellectual property laws. Such claims are questions of local concern, best answered by local authorities.

\section{B. Reproduction of Architectural Works}

The AWCPA also limits the copyright holder's right of reproduction. The new section 120(a) states that:

Pictorial Representations Permitted-The copyright in an architectural work that has been constructed does not include the right to prevent the making, distributing, or public display of pictures, paintings, photographs, or other pictorial representations of the work, if the buildimg in which the work is embodied is located in or ordinarily visible froin a public place. ${ }^{132}$

This provision is included both as a practical necessity and as a means to discourage trespass by tourists who try to photograph buildings not visible from a public vantage point. Enforcing limitations on the presence of copyrighted buildings in the foreground or background of photographs would prove impossible. Tourists and others inevitably would want to take photographs of landmark buildings. Questions about this ability of the public to take photographs or otherwise to make two-dinnensional reproductions of architectural works have been hotly debated in discussions of the copyrightability of architecture. ${ }^{133}$

132. AWCPA § 704(a), 17 U.S.C.A. § 120(a) (West Supp. 1992).

133. See Hearings on the AWCPA, supra note 24, at 70-71 (statement of Ralph Oman, Register of Copyrights) (two-dimensional representations are not necessary to provide architects with the economic incentives for creativity); id. at 125 (statement of David $\mathrm{K}$. Perdue on behalf of the American Institute of Architects) (supporting basic idea of limiting two-dimensional reproductions, but expressing fear that overbroad protection will allow infringing reproduction of copyrighted plans); id. at 138 (statement of Richard Carney on behalf of the Frank Lloyd Wright Foundation) (noting that commercial use of models and photographs of architectural works deprives architects of the "fruits of [their] labor ... without compensation").

As early as 1906, debate over the ability to photograph buildings derailed the imitial discussions of adding architectural works to the legislation that eventually became the Copyright Act of 1909 . See Copyright OfFice REPORT, supra note 17, at 76-78; 3 LegisLative History of THE 1909 COPYRIGHT ACr 179-83 (E. Fulton Brylawski \& Abe Goldman eds., 1976).

Failure to grant the right to prohibit photographs and other two-dimensional reproductions to holders of copyrights in architectural works demonstrates the United States' mimimalist approach to compliance with the Berne Convention. Nations adhering to the Berne Convention split as to whether architects are allowed to control the production of two-dimensional reproductions of their works. For example, the United Kingdom, Denmark, Finland, and Cyprus pernit two-dimensional reproductions of architectural works. Wargo, supra note 15, at 431. Belgium, Gernnany, and France 
The most severe criticism of section 120(a) is that it deprives architects of needed protection by being unnecessary and overbroad in its permissiveness. ${ }^{134}$ Section 120 (a) allows the production of even commercial representations of architectural works. As a result, section 120(a) deprives architects of a potentially lucrative source of secondary income on their most notable works. The issue is somewhat confused by the fact that copyright holders inay control the production of three-dimensional reproductions of a coinpleted building, but may not control the production of two-dimensional reproductions. ${ }^{135}$ This distinction may prove very imiportant to the sale of souvenirs and other mementos from tourist attractions. Commentators have justly criticized the "dubious" reasons for depriving an architect of a share in the income from two-dimensional souvenirs, but allowing him to profit from commercially produced threedimensional souvenirs. ${ }^{136} \mathrm{~A}$ better solution imght have been to prohibit two-dimensional reproductions, and to rely on the "fair use" provisions of the Copyright Act to prevent ouly commercial reproductions.

The field may become further confused by the fact that "sculptures" are still protected from unauthorized two-dimensional reproductions. Copyright holders in monumental nonfunctional works of architecture will be able to enjom production of photographs and other two-dimensional reproductions. For this reason, it would be to the advantage of an architect to categorize a work, if possible, as a section 102(a)(5) "sculptural work" instead of as a section 102(a)(8) "architectural work." Similarly, separable design elements that qualify as section 102(a)(5)

do not, although Germany makes an exception for architectural works located on public roads and Belgium makes an exception for two-dimensional reproductions necessary to the reporting of public events. Id. at $432 \&$ n.163. The French cases have generated some unusual results. Id. at 432 \& n.165 (citing the Last Tango in Paris hitigation, in which the filmmakers, who set many scenes in recognizable architectural spaces, avoided a verdict of infringement only because the spaces were not absolutely recognizable; and also citing a case arising under the French civil code, and not French copyright law, in which the artist Bernard Buffet was ordered to pay damages to the owner of a house depicted in a Buffet painting). For overviews of how various nations treat architecture under their intellectual property laws, see CoPYRIGHT OFFICE REPORT, supra note 17, at 157-93, Ginsberg, supra note 57, at 496 n.74; Michael Huet, Architecture and Copyright, UNESCO COPYRIGHT BULL. Vol. XIX, No. 4, at 14 (1985).

As elsewhere, Congress sought to provide only the minimum protection required to comply with the Berne Convention. See, e.g., Wargo, supra note 15, at 407 n.18-19.

134. Ginsberg, supra note 57 , at $494-97$ (stating that principles of fair use adequately protect the interest of the public to make pictorial representations for noncommercial purposes, and disputing the wisdoin of depriving the copyright holder of the right to control the commercial exploitation of copyrighted architectural works).

135. It should be noted that the new $\S 120$ (a) does not apply to the production of two-dimensional copies of $\S 106(a)(5)$ architectural plans or models. See Hearings on the AWCPA, supra note 24 , at $70 \mathrm{n} .32$. If it did, $\$ 120$ (a) would allow the copying of plans, thus depriving authors of their valuable right in the reproduction of plans.

136. Ginsberg, supra note 57, at 495. 
"sculptural works" enjoy protection from unauthorized two-dimensional reproductions. Thus, under the AWCPA, a manufacturer could commercially market postcards and posters of the Cathedral of Notre Dame in Paris (were the Cathedral copyrighted under American copyright law), but could not market posters or postcards of the famous gargoyles attached to the Cathedral.

\section{Forms of Relief Available Under the Act}

Once a copyright holder determines what claim will be brought, the litigant inust then determine what form of rehef will be sought. The Copyright Act of 1976 provides several forms of rehief: mjunctive rehef, ${ }^{137}$ statutory ${ }^{138}$ and actual damages, ${ }^{139}$ recovery of the defendant's profits, ${ }^{140}$ and impounding ${ }^{141}$ or destroying ${ }^{142}$ infringing copies. Injunctive rehef and destruction present particular problems when applied to architectural works. As enacted, the AWCPA permits copyright holders to seek injunctive rehef against the construction of infringing buildings, even if construction has already begun. Much of the debate over H.R. 3990 focused on the question of whether injunctive rehef was an appropriate remedy for infringement. ${ }^{143}$ As originally drafted, section 4 of H.R. 3990 permitted injunctive rehef ouly when construction had not "substantially begun." "144 The architectural commumity supported this pragmatic view, arguing that the economic waste attendant to the destruction of buildings already under construction should preclude the granting of injunctions in inost cases. ${ }^{145}$

Although Congress eventually decided to allow injunctive rehief under the AWCPA, ${ }^{146}$ defendants nay still suggest equitable reasons

137. 17 U.S.C. $\$ 502(a)(1988)$.

138. Id. $\S 504$ (c).

139. Id. § 504(b); see Intown Enters. v. Barnes, 721 F. Supp. 1263, 1266-67 (N.D. Ga. 1989) (plaintiff may recover profits on houses that it would have sold but for defendant's duplication of copyrighted architectural plans and use of infringing copies to build identical houses, it may also recover defendant's profits not accounted for in computing actual damages); see also Robert $\mathbf{R}$. Jones Assocs. v. Nino Hoines, 858 F.2d 274, 280-81 (6th Cir. 1988) (same).

140. 17 U.S.C. § 504(b); see Robert R. Jones Assocs, 858 F.2d at 280-81 (plaintiff may get infringer's profits where profits exceed actual damages); Joseph J. Legat Architects v. Umited States Dev. Corp., No. 84C8803, 1991 WL 38714 (N.D. Ill. Mar. 20, 1991).

141. 17 U.S.C. $\$ 503(a)$.

142. Id. $\S 503(\mathrm{~b})$.

143. H.R. REP. No. 735, supra note 70 , at 13-14, reprinted in 1990 U.S.C.C.A.N. at 6944-45.

144. H.R. 3990, supra note $69, \S 4$, reprinted in Hearings on the AWCPA, supra note 24 , at 5.

145. H.R. REP. No. 735, supra note 70, at 13 (statements of Michael Graves and AIA); Hearings on the AWCPA, supra note 24 , at 18-19, 117.

146. H.R. REP. No. 735, supra note 70, at 13-14, reprinted in 1990 U.S.C.C.A.N. at 6944-45. 
why an injunction should not be issued. ${ }^{147}$ In discussing the availability of permanent injunctive rehef under the Copyright Act of 1976, the United States Court of Appeals for the Second Circuit stated en banc that "[a]ll now agree that injunction is not the autonatic consequence of infringenent and that equitable considerations always are gernane to the determination of whether an injunction is appropriate."148 In the past, soine courts have refused to issue injunctions barring future construction of buildings based on copyrighted plans. ${ }^{149}$

Discussing the availability of injunctive relief for architectural works, the House Subcommittee noted that "architectural works may present issues different than other forms of authorship. Architectural works are the only form of copyrightable subject inatter that is habitable." 150 The Subcommittee noted that granting an injunction after construction had begun would lead to the waste of substantial preconstruction costs, and would create an added unpredictability for the many parties imvolved in construction, such as the financial backers of the project, the subcontractors, inaterials suppliers, and the unions. ${ }^{151}$ However, the Subcommittee did not consider these economic factors to be significant enough to warrant a departure froin the general rule that injunctive relief is an appropriate remedy for copyriglit infringenent. ${ }^{152}$ The Subcommittee noted that many of the saine econonic arguments could be inade for denying an imjunction for a motion picture project, but none for denying an mjunction for copyright infringeinent of a screenplay or completed film. ${ }^{153}$ As an equitable reinedy, an injunction will still require balancing the possibility of waste and other econonic liarms against the availability of alternative remedies.

147. The Subcommittee shared Graves's and the AIA's concerns about economic waste in addressing the injunction issue. The AIA argued for the exercise of discretion by a judge in determining the appropriateness of injunctive relief, stating that although it was conceivable that the very existence of a building would be an irreparable harm to a copyright holder, a judge in an injunctive proceeding should weigh the public policy considerations regarding economic waste against the interests of the copyright holder. Id. at 13, reprinted in 1990 U.S.C.C.A.N. at 6944; Hearings on the $A W C P A$, supra note 24 , at 117 .

148. New Era Publications Int'1 v. Henry Holt, Co., 884 F.2d 659, 661 (2d Cir. 1989) (en banc), cert. denied, 493 U.S. 1094 (1990).

149. See Nucor Corp. v. Tennessee Forging Steel Serv., Inc., 476 F.2d 386, 393 (8th Cir. 1973) (stating in dicta that an injunction should be issued only if "minimum construction had begun"); Edgar H. Wood Assocs. v. Skene, 197 N.E.2d 886, 896 (Mass. 1964) (no injunction given the excessive hardship to the defendant).

150. H.R. REP. NO. 735, supra note 70, at 13, reprinted in 1990 U.S.C.C.A.N. at 6944.

151. Id. at 13-14, reprinted in 1990 U.S.C.C.A.N. at 6944-45.

152. Id. at 14, reprinted in 1990 U.S.C.C.A.N. at 6945.

153. Id. at 14 n.28, reprinted in 1990 U.S.C.C.A.N. at 6945 n.28. 
The economic waste accompanymg an injunction against construction of an architectural work may preclude injunctive relief. Construction of a building requires significant costs by investors, banks, and tenants. These parties would all be greatly affected by an imjunction against construction of an infringing building. Destruction of an infringmg building entails even greater potential losses. Large economic costs, such as land acquisition costs, accompany a construction project long before construction begins. Compliance with local zoning and construction regulations, and engineering and legal fees impose similar costs. An injunction will disturb the repayinent schedule of construction loans and other forms of financing. Statutory or actual damages, or a returu of profits, may be more appropriate forms of rehef for infrimgements of architectural works.

If an injunction is not granted, courts still have broad authority to fashion appropriate rehef under the Copyright Act. For example, if injunctive rehef would impose an undue hardship on the infrimger, a court may instead require payment of a reasonable hicense fee for use of the copyright. ${ }^{154}$ Similarly, destruction of an infrimging copy may be ordered, although it is difficult to imagine that a court would order destruction, given the tremendous economic waste. ${ }^{155}$

A copyright holder must also determine against wliom a claim for relief should be pursued. Copyright law accepts claims of contributory infringement and vicarious liability. ${ }^{156}$ These doctrines serve to transfer liability to the ultimate beneficiaries of infrimgement. The doctrines of vicarious liability and contributory infringement are generally applicable to all copyright claims, and have found specific application in cases involving copyright in architectural plans. ${ }^{157}$

Courts find vicarious hability "[w] $[\mathrm{wen}$ the right and ability to supervise [the infringer] coalesce with an obvious and direct financial interest

154. 17 U.S.C. $\S 405(b)$.

155. NIMMER ON COPYRIGHT, supra note 50, $\$ 14.08$ (citing cases holding that destruction should be avoided to prevent "needless waste and best serve the ends of justice").

156. The Copyright Act of 1976 does not expressly include provisions for third-party liability for infringeinent. Sony Corp. of Am. v. Universal City Studios, Inc., 464 U.S. 417, 434-35 (1984). The Semiconductor Chip Protection Act of 1984 includes provisions for third-party liability. 17 U.S.C. $\S 905(3)$. However, these provisions are linited in application to semiconductors, and are not applicable to other copyright works. See Aitken, Hazen, Hoffinan, Miller, P.C. v. Empire Constr. Co., 542 F. Supp. 252, 261-62 (D. Neb. 1982) (defendant development coinpany held not hable for copyright infringement when contractor copied and used plaintiff's blueprints to construct building for defendant). Nonetheless, courts have long accepted that the doctrines of both vicarious liability and contributory infringement should be encounpassed by American copyright laws. Sony, 464 U.S. at 435.

157. Demetriades v. Kaufinan, 690 F. Supp. 289, 292 (S.D.N.Y. 1988); Aitken, Hazen, 542 F. Supp. at 261-62; Hernan Frankel Org. v. Tegman, 367 F. Supp. 1051, 1054 (E.D. Mich. 1973). 
in the exploitation of copyrighted materials." 158 If an architect infringes a copyrighted design, the chents of that architect may be liable for a claim of vicarious liability. Whether an architectural chent would be found hable would depend upon the level of control exerted by that client. Although not dealing with architectural works, soine copyright infringeinent cases suggest that the level of control must be relatively high. ${ }^{159}$ Lack of actual knowledge that the primary actor is engaging in infringing conduct will not protect the secondary actor from vicarious liability. ${ }^{160}$ Developers, investors, and contractors may also be subject to claims of vicarious hability. However, a plaintiff would have a inore difficult time demonstrating that these parties exerted the requisite level of control over the architect.

If a party does not have the relatively high level of "control" over the primary infringer needed to make a showing of vicarious liability, a contributory infringeinent claim may still be brought. In this way, a contractor or chient who did not exercise a great deal of control over the architect may be found liable for an infringing design by the arclitect. Two types of contributory infringement exist: conduct that furthers the infringement, and contribution of the means to infringe. ${ }^{161}$ A party who, "with knowledge of the infringing activity, induces, causes or materially contributes to the infringing conduct of another, may be held liable as a

158. Shapiro, Bernstein \& Co. v. H.L. Green Co., 316 F.2d 304, 307 (2d Cir. 1963). This standard illustrates the close connection of vicarious liability with the tort doctrine of respondeat superior. See also H.R. REP. No. 1476, 94th Cong., 2d Sess. 159 (1976) (noting that violators of the copyright owner's exclusive rights are infringers, including those who can be considered related or vicarious infringers), reprinted in 1976 U.S.C.C.A.N. 5659, 5775.

159. See Sony, 464 U.S. at 437 n.18 (defendant inust have some degree of control or supervision over the individual directly responsible for the infringement); Demetriades, 690 F. Supp. at 292-93 (realtors who arranged sale of land not liable because their financial interest in the infringing conduct was insufficient to establish vicarious hability).

160. See Italian Book Corp. v. Palms Sheepshead Country Club, 186 U.S.P.Q. 326 (E.D.N.Y. 1975) (rightclub owner hable for copyright infringement by orchestra that had rented premises, despite owner's lack of knowledge); Chappel \& Co. v. Frankel, 285 F. Supp. 798 (S.D.N.Y. 1968) (where record unanufacturer and distributor reproduced music compositions without licenses, defendant's lack of knowledge was irrelevant to issue of whether he participated in the infringement); see also Rexnord, Inc. v. Modern Handling Sys., Inc., 379 F. Supp. 1190, 1196 (D. Del. 1974) (defendant hable for infringement by printer even if defendant had instructed printer not to infringe when defendant supplied copyrighted materials to printer). Lack of knowledge of infringing conduct may, however, effect the availability of certain remedies. See NIMMER ON COPYRIGHT, supra note 50, $\$ 13.08$.

161. See Cable/Hoine Communications Corp. v. Network Prods., Inc., 902 F.2d 829, 845-47 (11th Cir. 1990) (despite lack of any direet participation in infringement, proinoter of pirate chip held liable as having contributed to infringement). 
'contributory infringer." "162 Knowledge of and participation in the infringing conduct are prerequisites to a finding of contributory infringeinent. ${ }^{163}$ The contribution of the party to the infringenent must be relatively high. ${ }^{164}$ The doctrine of contributory infringement was not intended to allow a plaintiff to bring a claim against all those who participated in the design process. Within the context of architectural infringement, the Umited States District Court for the Southern District of New York refused to allow a claim of contributory infringement against a real estate broker who had purchased the land upon which an infringing building was built, ${ }^{165}$ reasoning that the real estate broker did not have "substantial involvement" in the infringement. 166 The court stated that a "simple knowledge and benefit test would ... ensnar[e] individuals far too remotely or tangentially involved . . . ."167

\section{AUTHORSHIP AND COPYING: ESTABLISHING THE STATUTORY ELEMENTS OF A ClAIM FOR INFRINGEMENT UNDER THE ACT}

A claim for copyright infringement has two elements: (1) proof of ownership of a valid copyright, and (2) proof of copying of constituent

162. Gershwin Publishing Corp. v. Columbia Artists Management, Inc., 443 F.2d 1159, 1162 (2d Cir. 1971). Compare MacMillan Co. v. I.V.O.W. Corp., 495 F. Supp. 1134 (D. Vt. 1980) (shopping center owner hable under theory of contributory infringement after arranging for contractor to prepare drawings, then knowingly allowing the contractor's working drawings to be used in final plans prepared by others) with Hernnan Frankel Org. v. Tegman, 367 F. Supp. 1051, 1054 (E.D. Mich. 1973) (dismissing clients of architect as parties to copyright suit because they played no role in copying of plans in question) and Aitken, Hazen, Hofman, Miller, P.C. v. Empire Constr. Co., 542 F. Supp. 252, 261-62 (D. Neb. 1982) (finding engineer and lumber company that participated im infringing construction not liable absent knowledge on their part of copyright infringement) and Schuchart \& Assocs. v. Solo Serve Corp., 220 U.S.P.Q. 170 (W.D. Tex. 1983) (finding no contributory infringement by defendant corporation because it had no knowledge of infringement until after copying took place).

There are limits to the reach of contributory infringement. The party must have been " $\mathrm{m}$ a position to control the use of copyrighted works by others and had authorized the use without permission from the copyright owner." Sony, 464 U.S. at 437. But see id. at 488 n.39 (Blackmun, J., dissenting) (finding that actual "control" need not be shown).

163. Demetriades v. Kaufman, 690 F. Supp. 289, 293 (S.D.N.Y. 1988).

164. See id. at 293-94 (even if knowledge is found, slight imvolvement of realtors in infringing conduct is not enough to establish contributory infringement). The Demetriades court indicated that lad the defendants made available the drafting facilities or other copying equipment by which the plans or building were copied, they might liave been treated less sympathetically. Id.

165. Id. at 289.

166. Id. at 294.

167. Id. The Demetriades court cautioned that contributory infringement could be found if the real estate agent had some degree of control or contacts with the primary infringer for the purpose of providing direct assistance in the copying process. 
elements of the work that are original. ${ }^{168}$ Ownership of a valid copyright originates in authorship, although the author may assign or transfer ownership to another party. The differing roles of architect, client, architectural firm, engineers, and others in any architectural design raise questions of authorship of the original elements in that design. Proving the element of copying also presents interpretive questions when applied to architectural works. In general, evidence of actual copying is difficult to find. Given these difficulties, courts look to whether the defendant had access to the copyrighted work, and whether the allegedly infringing work bears a "substantial similarity" to the copyrighted work. If both access and substantial similarity are found, copying will be inferred.

\section{A. Substantial Similarity, the Standard for Infringement, and the Rule of Trademark Law}

Substantial similarity has proven to be one of the most problematic issues in copyright hitigation. In the oft-cited words of Judge Learned Hand, "[t]he test for infringement of a copyright is of necessity vagne." "169 Melville Nimmer notes that "the determination of the extent of similarity which will constitute a substantial and hence infringing similarity presents one of the inost difficult questions in copyright law, and one which is the least susceptible of helpful generalizations."170 For all copyrightable works, some degree of similarity must be tolerated. Creativity and progress would be impossible without limited forms of copying. The purposes of the copyright laws would be frustrated if designers and authors could not adapt, inodify, or otherwise improve existing forms. The difficulty arises in determining when similarity between works is minor and permissible, and when similarity is "substantial" and actionable. ${ }^{171}$

The architectural design process presents special problems in defining the hine between permissible and actionable similarity. As discussed earlier, architectural design is the arrangement of individual pieces of the architectural vocabulary into a coherent whole. ${ }^{172}$ More than other foruns of artistic expression, architecture relies on copying of existing

168. Feist Publications, Inc. v. Rural Tel. Serv. Co., 111 S. Ct. 1282, 1296 (1991). See generally NimmER on COPYRIGHT, supra note 50, $\$ 13.01-.03$ (outlining the types of evidence necessary to prove "ownership" and "copying").

169. Peter Pan Fabrics, Inc. v. Martin Weiner Corp., 274 F.2d 487, 489 (2d Cir. 1960).

170. Nimmer ON COPYRIGHT, supra note 50, § 13.03[A], at 13-23.

171. Easy cases exist, and would be similar to Arthur Rutenberg Corp. v. Dawney, 647 F. Supp. 1214 (M.D. Fla. 1986) (finding an infringement where defendants pressured architect to modify architectural plans until they were "substantially similar" to copyrighted plans).

172. See supra text accompanying notes 32-34. 
forms. Architects have long copied individual elements, patterns of arrangement, and spatial forms from other works, in a process known as "quoting." Although im rare cases architects create coinpletely new forms, more commonly, architects express their originality through the arrangeinent of preexisting forms. ${ }^{173}$

1. Comprehensive Nonliteral Similarity. Given the rehance of architecture on copying existing forms, courts will struggle in determining when a similarity is considered "substantial" under the AWCPA. Cases that arose outside of the context of architectural works may provide a useful framework for analysis. Nimmer's authoritative treatise on copyright law distinguishes two types of substantial similarity: "coinprehensive nonliteral similarity"174 and "fraginented literal similarity."175 The framework provided by this conceptual division should be apphed to architectural works. Comprehensive nonliteral similarity exists when "the fundamental essence or structure of one work is duphicated in another."176 Literal or verbatim copying need not be found for a finding of comprehensive nonliteral similarity. Similarly, section 703 of the AWCPA explicitly protects the overall shape of a building. The legislative history of the AWCPA states that "the aesthetically pleasing overall shape of an architectural work could be protected under this bill."177 This would apply to the general arrangement of elements imto an architectural work.

Most of the copyright infringement cases related to architectural plans involve straightforward situations in which the entire design, im all its details, was copied. When not all of the details are copied, the question of substantial similarity becomes more difficult. A showing of comprehensive nonliteral similarity wonld be difficnlt to demonstrate. For example, the Chrysler Building and the Empire State Building (see Figure 3) stand ten blocks apart from each other in New York City. Both are tall buildings sheathed in hight-colored stone, with many setbacks; both incorporate Art Deco decorative styles on their interiors and exteriors; both buildings have indented windows emphasizing the verticahty of the structures, and metal spires reaching to the sky. If these two structures were built today, could William Van Alen, architect of the Chrysler

173. See supra notes 33-34 and accompanying text.

174. NimMER ON COPYRIGHT, supra note 50, § 13.03[A][1].

175. Id. $\S 13.03[\mathrm{~A}][2]$. Nimmer's terminology has been picked up by several courts. See Walker v. Time Life Films, Inc., 784 F.2d 44 (2d Cir.), cert. denied, 476 U.S. 1159 (1986); Universal Athletic Sales Co. v. Salkeld, 511 F.2d 904 (3d Cir.), cert. denied, 423 U.S. 863 (1975); S \& H Computer Sys., Inc. v. SAS Inst., Inc., 568 F. Supp. 416 (M.D. Tenn. 1983).

176. NIMMER ON COPYRIGHT, supra note 50, § 13.03[A][1].

177. H.R. REP. No. 735, supra note 70, at 21, reprinted in 1990 U.S.C.C.A.N. at 6952. 
Building, claim that the coinbination of eleinents of the Empire State Building constitute comprehensive nonliteral similarity to his building?

In answering this question, one must look to the degree to which the architect's creativity is expressed in the combination of elements. Courts must isolate the eleinents, or combination of elements, that are inost expressive of the architect's creativity. For example, the fact that both the Chrysler and Empire State Buildings use a setback design is not greatly expressive of their architects' creativity, as a setback design was required of tall buildings under New York's zoning laws during the 1920s and 1930 s, and was at the time also the most effective way to solve the construction problems faced by tall buildings. In addition, the metal spires were also used for reasons of functionality (i.e., to allow for use as radio towers). A court assessing coinprehensive nonliteral similarity should first separate out the design elements that are functionally required, and evaluate substantial similarity on the basis of the original design elements that are expressive of the architect's creativity. ${ }^{178}$

The exact proportions chosen by the respective architects would be the element most expressive of the architect's creativity, and should therefore be the focus of an analysis based on comprehensive nontiteral similarity. From a policy perspective; this helps to encourage architectural creativity. Architects must be allowed to tinker with existing copyrighted designs, making sinall but significant changes im order to improve these designs and adapt them to new contexts. 179

Certainly, at some poimt, similarity of the overall design of a building rises to the level of infringement. However, trademark law inay provide a more appropriate forum, with a lower threshold for a showing of infringement. At some point when not all of the eleinents of an architectural work are copied, an architect's original artistic expression will not he in a single, specific design. Rather, a certam coinbination of elements will be the "signature" of that architect. By varying this combination of elements to individual circuinstances, an architect may be able to create a

178. See discussion of the East/West case, supra note 99 , in which the court found that infringement cannot be found for elements of an architectural design dictated by the configuration of the property.

179. See Wickham v. Knoxville Int'1 Energy Exposition, Inc., 555 F. Supp. 154 (E.D. Tenn. 1983), affd, 739 F.2d 1094 (6th Cir. 1984). In this case, two architects designed world's fair centerpieces featuring spheres atop nonfunctional towers. The court found that there was no substantial similarity, in light of the differences im proportions and sliapes of the spheres. "Plaintiff seems to be asserting that he has the exclusive riglit to design and erect a tower with a spherical building on top of it. The use of towers in architectural design is certainly not unique. . . . Likewise the incorporation of a spherical structure imto the design is no more than an 'idea." Id. at 156. The architectural drawings in Fignre 4 show the similarities between the two designs for the "Sunsphere" that were nonetheless insufficient to rise to the level of substantial similarity. 
valuable ongoing franchise. ${ }^{180}$ Protectible artistic expression may lie in the basic coinbination of eleinents. ${ }^{181}$

When an architect creates a "signature" style, copyright law must be careful not to prevent other architects from improving on his designs. When an architect makes significant alterations or inodifications to an existing, copyrightable style, that new design should not be considered to infringe the earlier design.

2. Trademark Protection of Architectural Works. A "signature" style of an architect is more properly protected under trademark law. Trademark law, not copyriglit law, is the appropriate forum for designs that tend to confuse the relevant marketplace. Reproduction of the most distmctive aspects of an architect's style may confuse the architectural marketplace. Confusion of a limited group can constitute the confusion required under the Lanham Act. ${ }^{182}$ Confusion does not require that the identity of the trademark holder be known. Courts should realize that architecture is itself a service busmess, and that in some limited situations, a buildimg design may take on secondary meaning and become a means of identification of origin susceptible to confusion and deception. Trademark law is qualitatively different from patent and copyriglit. ${ }^{183}$

Property im the use of a trade-mark ... bears very hittle analogy to that which exists in copyrights or in patents for new inventions or discoveries, as they are not required to be new, and may not involve the least invention or skill in their discovery or application. Phrases, or even words in common use, inay be adopted for the purpose, if, at the time of their adoption, they were not employed by another to designate the same or similar articles of production or sale. ${ }^{184}$

180. "Often repetition of [an architect's] basic designs is the means whereby he collects the bulk of his fees." John F. Gisla, Comment, Copyright Protection for Architectural Structures, 2 U.S.F. L. REV. 320, 327 (1967-68).

181. One commentator has cited Frank Lloyd Wright's Prairie Houses as an example of such repetition. The Prairie Houses are residential structures, designed with the environmental consideratious of the Midwest in mind, that had the common design elements of low overhanging roofs, broad rows of casement windows, large open fireplaces made of stone, open floor plans, and natural materials such as locally available wood and stone. Brainard, supra note 32, at 95 n.110. The combination of these elements created a distinctive and very popular style, which Wright reproduced many times, deriving a lucrative income therefrom. Many architects imitated this basic style.

182. See Joseph J. Legat Architects v. United States Dev. Corp., 625 F. Supp. 293, 299-300 (N.D. Ill. 1985) (likelihood of confusion may be shown if subcontractors and future readers of the Department of Housing and Urban Development and County Planning Board records could be confused).

183. Federal trademark law, unlike patent and copyright law, is not constitutionally grounded in the encouragement of the "useful arts." The Lanham Act is instead founded on the federal power to regulate interstate commerce, serving the policy purpose of avoiding confusion or deception in the marketplace and protecting identifying symbols. Anti-Monopoly, Inc. v. General Mills Fun Group, 611 F.2d 296, 300-01 (9th Cir. 1979).

184. McLean v. Fleming, 96 U.S. 245, 254 (1877). 
The general federal unfair competition provision, section 43(a) of the Lanham Act, proves the most useful provision for a finding of trademark infringement of architectural works. ${ }^{185}$ The protectible "trade dress" of an object can mclude such diverse product features such as its design, size, shape, color, packaging, labels, graphics, or service business features such as the retail decor of an establishment, its architectural features, its layout and floor plan, and even the uniforms of the employees. ${ }^{186}$ Eligibility for trade dress protection is established by showing that the trade dress is nonfunctional and inherently distinctive. ${ }^{187}$ Infrimgement is shown by a use that would create the likelihood of confusion.

Functionality is the most significant hurdle for trademark protection of architectural works. Trade dress features are not eligible for trademark registration if they are primarily functional or utilitarian in nature. ${ }^{188}$ The easiest cases imvolve external, largely nonfunctional

185. Section 43(a) provides:

(a) Any person who, on or in connection with any goods or services, or any container for goods, uses in commerce any word, term, name, symbol, or device, or any combination thereof, or any false designation of origin, false or misleading description of fact, or false or misleading representations of fact, which-

(1) is likely to cause confusion, or to cause mistake, or to deceive as to the affiliation, connection, or association of such person with another person, or as to the origin, sponsorship, or approval of his or her goods, services, or commercial activities by another person, or

(2) in commercial advertising or promotion, misrepresents the nature, characteristics, qualities, or geographic origin of his or her or another person's goods, services, or commercial activities,

shall be hable in a civil action by any person who believes that he or she is or is likely to be damaged by such act.

Lanham Act $\S 43($ a), 15 U.S.C. § 1125(a) (1988).

The fact that an object is three-dinnensional poses no bar to fitting soinething within the scope of the Lanham Act. See, e.g., Jerome Gilson, Trademark Protection and Practice § 1.02[1] (1991) (giving example of the Pepperidge Farm Goldfish Cracker, SN \# 73-705,855, as an illustration of a registrable three-dimensional trademark). Three-dimensional objects can be "goods," "symbols," "devices," or "combinations thereof" for the purposes of the Act.

186. See Two Pesos, Inc. v. Taco Cabana, Inc., 112 S. Ct. 2753, 2755 (1992) (distinctive Mexican motif of restaurant protectible as trade dress); GiLsoN, supra note $185, \S 7.02[7][\mathrm{c}]$ \& n.116.

187. Two Pesos, $112 \mathrm{~S}$. Ct. at $2757-58$.

188. In re Honeywell, Inc., 532 F.2d 180 (C.C.P.A. 1976) (thermostat cover functional and therefore not registrable for trademark); see also Keene Corp. v. Parafiex Indus., Inc., 653 F.2d 822, 824 (3d Cir. 1981) (outdoor luminaire design functional and therefore not protected by trademark). Patent law, and not trademark, is the vehicle for protecting functional designs. Allowing functional objects to receive trademark protection would be inconsistent with the purpose of trademark law: to promote fair competition. This purpose would be frustrated by granting trademark protection to subject matter such as functional designs, whose presence in the inarketplace would encourage competition. Competition is assisted, not harmed, by free access to functional aspects of a design that might be needed by others to improve their products. See Stormy Clime Ltd. v. ProGroup, Inc., 809 F.2d 971, 977-78 (2d Cir. 1987) (patent law, and not trademark, is proper forum for protection of functional design); Paraflex, 653 F.2d at 824 (trademark should not be used to grant a limited monopoly in features that would fail to qualify for patent protection); Freddie Fuddruckers, Inc. v. Ridgeline, Inc., 589 F. Supp. 72, 77 (N.D. Tex. 1984) (public interest in increasing competition 
decorative elements on architectural structures. ${ }^{189}$ More difficult cases involve claims of trademark infringement of the entire constructed design of a structure. Some authorities have viewed the inherent functionality of all works of architecture as a significant barrier to trademark protection of buildings and other completed architectural works. ${ }^{190}$ This represents far too broad a conception of functionality. ${ }^{191}$ A design should be

provides policy justification for fuuctionality requirement), aff' mem., 783 F.2d 1062 (5th Cir. 1986).

189. External architectural features that have been found copyrightable imclude: the coloring of a fence used by a company that rents fences, In re Eagle Fence Rentals, Inc., 231 U.S.P.Q. 228 (T.T.A.B. 1986); a jagged hine design on the exterior of an automobile tune-up business, Precision Tune, Inc. v. Tune-A-Car, Inc., 611 F. Supp. 360 (W.D. La. 1984); the use of a broad red band across a store front, United Cigar Stores Co. of Am. v. Umited Confectioners, 113 A. 226 (N.J. Ct. Err. \& App. 1921) (infringer was on same store block as trademark claimant). Interior architectural features are similarly subject to trademark. However, the cases involving imterior architectural design elements have proven more difficult for trademark claimants to win, as courts have been reluctant to deprive competitors of necessary design elements and themes. Courts have indieated that the use of specific design elements may be enjoined, but that the use of general design themes may not be enjoined. See Warehouse Restaurant, Inc. v. Customs House Restaurant, Inc., 217 U.S.P.Q. 411 (N.D. Cal. 1982) (pernnanently enjoining use of "particular item of interior decor" of dining booths encased in packing crates, but permitting general elements of Polynesian theme in restaurant); Associated Hosts of Cal. v. Moss, 207 U.S.P.Q. 973 (W.D.N.C. 1979) (temporarily enjoining the operation, construction, and franchising of defendant's restaurants that were substantially identical copies of the entire theine of plaintiff's restaurant), appeal dismissed, 726 F.2d 480 (9th Cir. 1984). But see T.G.I. Friday's, Inc. v. International Restaurant Group, Inc., 405 F. Supp. 698, 705 (M.D. La. 1975), affd, 569 F.2d 895 (5th Cir. 1978) (refusing to cnjoin use of turn-of-the-century decor in restaurants, imcluding use of Tiffany launps, stained glass, tin pictures, and other features, even though court found that "Saturday's 'trade dress' mirrors that of Friday's"). See generally Altman, supra note 24, at 650-54 (listing relevant cases).

190. The Trademark Office, for exaunple, takes a very limited view, stating in the Manual of Exanining Procedure of the Umited States Patent and Trademark Office that "the configuration of an actual three-dimensional building, in and of itself, is not registerable [for trademark protection], since as a building it would be no more than functional, as housing." MaNUAL of Examining Procedure of the United States Patent and Trademark Office $\$ 1301.08$ (1983). However, caselaw does not support the view of the Trademark Office. See Altunan, supra note 24, at 65254.

191. When an architectural design is dictated by structural, enginecring, or other practical necessities, that design should be found functional and unprotectible for trademark purposes. See Fotomat Corp. v. Photo Drive-Thru, Inc., 425 F. Supp. 693, 704-08 (D.N.J. 1977) (holding that Fotomat booths were not infringed as competitor's booths were similar ouly in functional aspects, and different in nonfunctional aspects). When a design is not dictated by these practical necessities, or when a design represents the choice of one of many equally functional options available to solve the same design problem, then that design should be considered nonfunctional and therefore protectible.

In many cases, an architectural design is not functionally dictated. See White Tower Sys., Inc. v. White Castle Sys. Corp., 90 F.2d 67 (6th Cir.) (upholding finding of trademark infringement after finding that use of castle design was not functionally required for haunburger restaurant), cert. denied, 302 U.S. 720 (1937). An architect and client will often have a wide variety of possible solutions to the same design problem, all of equal utility. In such cases, when the architect chooses a particular design from a wide variety of equally useful alternatives, functionality does not act as a bar to competition, and should not bar trademarkability. See Taco Cabana Int'1, Inc. v. Two Pesos, Inc., 932 F.2d 1113, 1119 (5th Cir. 1991) (" "The wide range of . . . design options allows a producer 
considered de jure functional if it is "the best or one of a few superior designs available." 192 When an architect's design is the most functional solution to a particular design problem, then patent law, not trademark, is the appropriate forum for protection. Courts must analyze the functionality of architectural works consistent with the core pohcy consideration underlying the functionality exception: whether permitting trademark protection of a design with secondary meaning will deprive competitors of a design necessary for them to compete. Competitors should be allowed to use individual design elements that do not, in themselves, contain secondary meaning. ${ }^{193}$ Protection should be afforded to "a combination of visual elements "that, taken together, ... nnay create a distinctive visual impression," "even if soine of these eleinents are functional. ${ }^{194}$

Once a test for functionality is established for architectural works, the next question is how to determine which works have a "distinctive character" and "secondary meaning." These elements are easiest to establish in the case of franchises of commercial enterprises. ${ }^{195}$ However, application of this test to buildings would be strictly limited by the statutory requirements of non-obviousness, novelty, and secondary meaning. Only a very sinall number of designs could fulfill these standards.

3. Fragmented Literal Similarity. Fragmented literal similarity also presents problems when applied to architectural works. The difficulty here is that the architectural design process has long accepted the "quoting" of individual design elements. The fact that the AWCPA excludes "individual standard features" from protection is one indication that claims of fragmented literal similarity with respect to architectural works should not be lieard. Architects must be allowed to copy individual elements. However, the copying of groups of elennents may rise to the level of substantial similarity. When several elements are combined into

to appropriate a distinctive identity without unduly hindering his competitors' ability to compete.' Taco Cabana's particular integration of elements leaves a multitude of alternatives to the upscale Mexican fast food industry that would not prove confusingly similar to Taco Cabana's trade dress.") (quoting Sicilia Di R. Biebow \& Co. v. Cox, 732 F.2d 417, 426 n.7 (5th Cir. 1984) (enphasis added), aff'd on other grounds, 112 S. Ct. 2735 (1992)).

192. Taco Cabana, 932 F.2d at 1119 n.6; In re Morton-Norwich Prods., Inc., 671 F.2d 1332, 1341 (C.C.P.A. 1982).

193. See Chevron Chem. Co. v. Voluntary Purchasing Groups, Inc., 659 F.2d 695, 703 (5th Cir. 1981), cert. denied, 457 U.S. 1126 (1982).

194. Fuddruckers, Inc. v. Doc's B.R. Others, Inc., 826 F.2d 837, 842-43 (9th Cir. 1987) (quoting Chevron Chemical, 659 F.2d at 703).

195. See, e.g., White Tower Sys, 90 F.2d at 67 (plaintiff's white castle-shaped building was pecuhar to its business and protected by trademark); Fotomat Corp. v. Cochran, 437 F. Supp. 1231 (D. Kan. 1977) (shape of roof of plaintiff's photo developing services drive-in was distinctive and arbitrary, therefore meriting trademark protection). 
a portion of a building, this combination may rise to the level of an expression of the architect's creativity. As with comprehensive nonliteral similarity, no hard and fast rules can be stated for the determination of when fragmented hteral similarity rises to the level of infringement. The qualitative value of the quoted elements to the overall work is one important factor. If the quantity of the quoted material is relatively small, but is qualitatively important to the overall work, substantial similarity may be found. 196

The challenge for courts is to craft a standard for fragmented hiteral similarity that will protect the original and creative expression of architects without removing design elements from the palette available to other architects. In addressing themselves to this challenge, courts must keep in mind the practical needs of the architectural profession in incremental innovation and in the quoting of existing works. Courts should also keep in mind that design patent and trademark are alternative forins of protection. Design patent or trademark law will often be a inore appropriate means to protect the elements that would be protected by fragmented hiteral similarity. For example, the broken pediment crowning the AT\&T Building in New York is ouly one isolated element of that building. Allowing copyright of this element would preclude use of this feature in all buildings, potentially preventing new, creative uses of this form. The impact of copyright protection would be very great, because the long terin of copyright protection and the absolute prohibition of copyright on all uses of the copyrighted work are significant constramts. ${ }^{197} \mathrm{~A}$ better, less restrictive forum for the protection of such works would be trademark protection. AT\&T could seek trademark protection of the pediment against other buildings that cause confusion or disparagement of AT\&T's unique corporate icon, without invoking the broader protection of copyright. ${ }^{198}$ Design patent law would also be available, although the statutory requirement of non-obviousness might make patent mipossible to achieve. ${ }^{199}$

196. Roy Export Co. v. Columbia Broadcasting Sys., Inc., 503 F. Supp. 1137 (S.D.N.Y. 1980) (copying one minute and fifteen seconds froin inotion picture sufficient to establish substantial similarity), aff'd, 672 F.2d 1095 (2d Cir.), cert. denied, 459 U.S. 826 (1982); Meredith Corp. v. Harper \& Row, Publishers, Inc., 378 F. Supp. 686, 690 n.12 (S.D.N.Y.) ("[E]ven a sinall usage inay be unfair if it is of critical importance to the work as a whole ...."), affd, 500 F.2d 1221 (2d Cir. 1974); Henry Holt \& Co. v. Liggett \& Myers Tobacco Co., 23 F. Supp. 302 (E.D. Pa. 1938) (copying three sentences in advertisement sufficient to establish "substantial" similarity).

197. See Herman Frankel Org. v. Tegman, 367 F. Supp. 1051, 1054 (E.D. Mich. 1973) ("This result protects agaiust copying of copyrighted material, yet does not change the copyright act into a patent act and give the person holding the copyright a monopoly on the ideas there expressed.").

198. Trademark protection is limited to preventing the use of a trademarked item in the same market. Copyright does not include any such limitation.

199. See supra notes $100-09$ and aecompanying text. 


\section{B. Authorship}

Authorship is the other element of a claim of copyright infringement. The architect, client, architectural firm, and engineers involved in an architectural project all play different roles in the design and construction process. The level of participation of eacli party varies for each project: their very roles vary with each project. Because each party contributes to the design, questions of authorship arise.

One does not have to be a licensed architect to be a copyright "author."200 Many parties contribute to the production of an architectural design. ${ }^{201}$ In this respect, the creative process for architecture is closer to that of filmmaking or the theater than to novel writing, painting, sculpture, or songwriting. ${ }^{202}$ The chent, the financial backer, the engineer, the contractor, and the ultimate inhabitants of a project all have a voice in the design process. Although all of these parties may inake some claim to have played some part in the design, only in unusual design relationships will anyone other than the architect be the one to coordinate the ideas of these parties and give them spatial expression. ${ }^{203}$

Prior to the AWCPA, courts addressed many of the most important questions relatimg to the authorship of architectural works. In fact, architectural works have been the focus of some of the most frequently cited cases regarding works for hire and joint authorship. However, these cases arose in the context of copyright in architectural plans. Analysis of issues of authorship in completed architectural works present somewhat different factual characteristics. Completion of architectural works, as distinct from architectural plans, requires the involvement of a greater number of parties. Those parties who become involved, including engineers and contractors, may in effect take over the project, and may merely consult with the architect when ambiguities arise. However, an analysis of the relevant legal standards indicates that the end result will be the same as it was before the extension of copyright to completed works-that only in unusual architect-chient-contractor relationships will authorship be found im parties other than the architect. ${ }^{204}$

200. The constitutional and statutory conception of an "author" requires no special training, level of skill, or professional or public recognition. See Goldstein v. California, 412 U.S. 546, 561 (1973) ("author" to be broadly construed to effectuate constitutional purpose of copyright laws).

201. CuFF, supra note 40 , at 13 ("The fundamental point is a simple one: the design of our built environment emerges from collective action.").

202. Id. at 56.

203. Id. at 61 .

204. However, this analysis must always be done on a case-by-case basis. The relationship between client, architect, and architectural firm in individual cases continues to define the ownership of the copyright. 
1. Works for Hire. The Copyright Act recognizes that all works "prepared by an employee within the scope of his or her employment" are considered to be "works made for hire."205 Classification as a work for hire carries important substantive consequences. If a work is considered a work for hire, "the employer or other person for whom the work was prepared is considered the author for [copyright] purposes, and, unless the parties have expressly agreed otherwise in a written instrument signed by them, owns all of the rights comprised in the copyright."206 Works for hire questions arise when architectural firms or chents claim ownership of the copyright in the work of an einployed architect. Works for hire disputes thus bear upon a plaintiff's ability to demonstrate ownership of a valid copyright and a defendant's ability to assert a defense that a plaintiff architect lacked copyright ownership. ${ }^{207}$ Classification of an architectural work as a work for hire also affects the duration of the copyright. ${ }^{208}$ Determining the proper author is important if the architect and the employer are froin different nations, as the copyrightability of an architectural work is determined by the nationality or doumicile of its author if the work is not pubhished in the Umited States. ${ }^{209}$ A work for hire created with the United States Government as the employer is not ehigible for copyright protection. ${ }^{210}$

Usually, an architect works alone, or as a nuember of a partnership or architectural firm. An mdividual architect may liave a formal longterm employinent agreeinent with a firm, or a more informal short-term relationship. The architect may work on the entire structure, or on discrete parts of the project. The individual architect, or his firm, is hired by the client. The chent and arclitect may have an ongoing relationship, which nuay even be exclusive. In some cases, architectural departments nuay be divisions of larger non-architectural compamies, working exclusively for one client. In all of these relationships, the client may or inay

205. 17 U.S.C. $\S 101$ (1988). The Copyright Act recognizes a second category of works, those "specially ordered or commissioned for use as a contribution to a collective work," to be works for hire. Id. However, these collective works are limited to clearly defined subject matter categories, of which architecture is not a part.

206. Id. § 201(b).

207. See M.G.B. Homes, Inc. v. Ameron Homes, Inc., 903 F.2d 1486, 1490 (11th Cir. 1990) (works for hire doctrine may arise as a defensive tactic); Easter Seal Soc'y v. Playboy Enters., 815 F.2d 323, 333 (5th Cir. 1987), cert. denied, 485 U.S. 981 (1988).

208. The normal copyright term is for the life of the author plus fifty years. 17 U.S.C. $\$ 302$ (a). The term for works for hire is seventy-five years from the first publication of the work, or one hundred years from the date of creation, whichever expires first. Id. $\S \S 302(\mathrm{c}), 303$.

209. Id. § 104(b)(1), (b)(5).

210. Id. $\S 105$. 
not be the ultimate owner of the finished work. One study of the architectural profession concluded that "[a]rchitects, more than other professionals, remain tied to their patrons."211

A reexamination of these cases in light of the 1989 Supreme Court redefinition of the works for hire standard in Community for Creative Non-Violence v. Reid ${ }^{212}$ indicates that courts will refuse to find the normal architect-client relationship to be one subject to the works for hire doctrine. Disputes in works for hire cases generally arise in determining whether an architect was an employee or whetler tlie architect was an independent contractor. The Court stated in $C C N V$ v. Reid that "[i]n determining whether a hired party is an employee under the general common law of agency, we consider the hiring party's right to control the manner and means by which the product is accomplished." 213 An im. portant element to note in this standard is that it looks to the right to control the manner and means of production, and not to the right to control the product itself.214 The CCNV v. Reid Court did not find it determinative that CCNV directed much of Reid's work.215 Ratler, the Court looked to many factors indicative of lack of control over means and methods of production, such as the artist's supplying lis own tools and workplace, the fact that the employer hired the artist for a fixed period of time with no right to assign additional projects, payment upon completion of a specific job, retention by the artist of discretion in determining his work schedule and compensation of assistants, and payment of payroll taxes or einployment benefits usually associated with an employer-employee relationship. ${ }^{216}$

As applied to the architectural profession, this standard indicates that architects hired by chients for individual projects will not be considered to have produced works for hire. ${ }^{217}$ Only unusual architect-client relationships will provide the client with control over the manner and

211. CufF, supra note 40 , at 33 .

212. 490 U.S. 730 (1989).

213. Id. at 751.

214. Nimmer on Copyright, supra note $50, \S 5.03$ [B], at 5-21.

215. 490 U.S. at 752.

216. Id. at $752-53$.

217. See Joseph J. Legat Architects v. United States Dev. Corp., 625 F. Supp. $293,297.99$ (N.D. III. 1985) (despite defendant's contractual authority to approve or veto the plans, the inability to supervise and control the architect's work placed case outside the work for hire doctrine); Meltzer v. Zoller, 520 F. Supp. 847, 857 (D.N.J. 1981) (homeowner not "author" under work for hire doctrine, even though he prepared sketches for, and otherwise gave ideas to, architect). But see Robert R. Jones Assocs. v. Nino Homes, 686 F. Supp. 160 (E.D. Mich. 1987) (involving copyright holder who generated idcas and concepts, then hired an architect to execute plans and drawing; court noted that the builder who provided the ideas was the copyright holder, but did not indicate in its opinion whether his status as author was the product of law or by assignment of rights by contract), aff'd on other grounds, 858 F.2d 274 (6th Cir. 1988). 
Ineans, therefore subjecting the work produced to the works for hire doctrine. ${ }^{218}$ The custom of the architectural profession is for the architect, and not the chent, to retain ownership in the drawings and plans prepared. ${ }^{219}$ Works produced by architects employed by architectural firms will, however, be considered works for hire. The usual architect-architectural firm relationship contains elements of control of the ineans and inanner of production. A closer question may be presented by architectural firms, or independent architects, who work primarily or exclusively with one client. Standards will einerge as the $C C N V$ v. Reid criteria are apphied on a case-by-case basis. Of course, employinent agreements between architects and their firms, and between architects and their chents, nay alter the ownership of copyrights.

The AWCPA's recognition of coinpleted architectural works as copyrightable subject inatter will allow contractors who hire architects to be considered authors of the coinpleted architectural work under the works for hire doctrine. Contractors will have the control over the inanner and means of production of the coinpleted work, as required in the $C C N V$ v. Reid test. However, contractors will still be unable to claim copyright in the architectural plans prepared by the architect, because the contractor will not generally have the requisite level of control over preparation of the plans. When a contractor hires an architect, these parties may determine that having one party own the copyright in the coinpleted work and the other party own the copyright in the plans is a confusing or otherwise troublesolne situation. An assignment of rights by one party is the best way to avoid this problem.

A separate probleın is posed by later revisions to coinpleted buildings: Should these revisions be considered architectural works of their own, and therefore worthy of their own copyrights, or should these revisions be considered "suppleınentary works" "revising ... or assisting in the use of the other work ..."?220 In this respect, architecture poses special problems to copyright law in that it is the one subject inatter category of copyright most likely to be revised at a later date.

218. See Aitken, Hazen, Hoffman, Miller, P.C. v. Empire Constr. Co., 542 F. Supp. 252, 258 (D. Neb. 1982) (builder did not have right to control and direct detail and means of work of the architect; therefore he could not satisfy requirements of works for hire doctrine).

219. AIA Document B141, the standard form contract for architects, which is jointly sponsored by the AIA, general contractors, and realtors, provides for ownership by the architect. AIA Standard Form Contract, supra note 41, art. 6. The Southern District of New York has recognized this to be the standard of the profession. See Kunycia v. Melville Realty Co., 755 F. Sup. 566, 572 (S.D.N.Y. 1990). But see Intown Enters. v. Barnes, 721 F. Supp. 1263, 1264 (N.D. Ga. 1989) (architect found to fall withm work for hire doctrine when working for chent). One shonld also note that the custom of the mdustrial design profession, whose members sometimes function as architects, is to transfer ownership and rights in plans to the chent. Kunycia, 755 F. Supp. at 568 n.1.

220. 17 U.S.C. $\S 101$ (1988). 
The most famous recent example of a revision is the Whitney $\mathrm{Mu}-$ seum of American Art in New York City. Hoping to expand its available floor space, the Whitney asked Michael Graves to create an additional wimg to Michel Breuer's original museum. Given the limited space at Whitney's Manhattan site, Graves proposed a design that was physically attached to both the side and the top of the original building. Critics and others felt that Graves's design significantly altered Breuer's historical building, and turned to the New York Landmark Law for protection. The copyright question raised in this dispute was who could claim authorship im the new addition. A strict application of the doctrine of supplementary works indicates that Breuer, and not Graves, should be considered the author of the new addition. ${ }^{221}$ Authority borrowed from other subject matter provisions of the Copyright Act also indicates that these works should be considered suppleinentary works. ${ }^{222}$

2. Joint Authorship. The Copyright Act recoginizes the concept of the "joint work," that is, a work "prepared by two or more authors with the intention that their contributions be merged into inseparable or interdependent parts of a umitary whole."223 Authorship in the entirety of the joint work is held equally and indivisibly by each contributor. ${ }^{224}$ Joint authors must intend, during preparation of the work, that their work be a jomt effort.225 The "intention that their contribution be merged" need not be in writing, 226 and the contribution of each author does not have to be qualitatively or quantitatively equivalent, or prepared in similar ways or with any day-to-day contact with the other authors. ${ }^{227}$ Some chents have attempted to be considered joint authors of the building they have commissioned. However, the cases establish that normal

221. A supplementary work is:

a work prepared for publication as a secondary adjunct to a work by anotlier author for the purpose of introducing, concluding, illustrating, explaining, revising, commenting upon, or assisting in the use of the otleer work, sucl as forewords, afterwords, pictorial illustrations, maps, cliarts, tables, editorial notes, inusical arrangements, answer material for tests, bibliographies, appendixes, and indexes.

Id. There are six otler categories of specially commissioned works that could be categorized as works for hire, but which have no relevance to architectural works. See id.

222. Id.

223. Id.

224. Id.; see Meltzer v. Zoller, 520 F. Supp. 847, 857 (D.N.J. 1981).

225. Edward B. Marks Music Corp. v. Jerry Vogel Music Co., 140 F.2d 266, 267 (2d Cir. 1944); see also Ashton-Tate Corp. v. Ross, 916 F.2d 516, 522 (9tlı Cir. 1990) (joint authorship of a prior work not itself sufficient to make developer joint author of derivative work); N1MMER ON COPYRIGHT, supra note $50, \S 6.03$ ("The essence of joint autliorslip is a joint laboring in furtherance of a preconcerted design.").

226. NIMMER ON COPYRIGHT, supra note $50, \S 6.03$.

227. Edward B. Marks Music Corp. v. Jerry Vogel Music Co., 42 F. Supp. 859, 863-64 (S.D.N.Y. 1942), affd, 140 F.2d 266 (2d Cir. 1944). 
client participation does not transform a client into an autlior of an architectural work. ${ }^{228}$ The AWCPA does nothing to change this principle. Because this question is addressed on a case-by-case basis, unusual architect-client relationships could lead to different results.

A more interesting question is posed by architects working together. Different architects or firms inay divide design responsibilities for interiors, exteriors, or the structural design of a building. Because the AWCPA refers to the entire building as the protectible "architectural work," and does not consider individual parts of a building to be separately protectible, architects working together would likely be considered joint authors.

3. Assignment. All or part of the author's copyright in an architectural work may be assigned or otherwise transferred.229 The custom of the trade has been for the architect to retain copyright im his work, rather than to assign his rights to the chent or owner of the work. ${ }^{230}$ Given the limited scope of the riglits granted in the AWCPA, this will probably contimue to be the custoin of the trade. Architects testified before Congress that if the AWCPA gave architects too many rights in the coinpleted work, architects would be asked to assign their copyrights in the finished work to the chents. ${ }^{231}$ This concern resulted in the provisions of section 704(a) of the AWCPA, granting the owners of a building the right to alter or destroy buildings without the consent of the architect. 232

Under the AWCPA, assignment of rights inay be appropriate in many circumstances. A builder who commissions an architect to design homes for a multi-unit development may want to have the architect assign the right of reproduction if the builder contemplates expansion of the development beyond its original scope. By domg so, the builder will be able to retam a consistent or uniforin design for the houses of the development. The owners of a landmark work may want to retain the right to create three-dimensional reproductions of the work if models or other souvenir reproductions of the work have some marketability. Any

228. E.g., M.G.B. Homes, Inc. v. Ameron Homes, Inc., 903 F.2d 1486 (11th Cir. 1990) (holding that house builder who submitted thumbnail sketches of house floor plan to drafting company, reviewed work in progress, and had final approval authority, was not a coauthor of copyrighted final fioor plan for purposes of Copyright Act).

229. 17 U.S.C. $\S 201(d)(2)$ (1988); id. § 101 (definition of "transfer of copyright ownership").

230. See AIA Standard Form Contract, supra note 41.

231. See Hearings on AWCPA, supra note 24, at 16 (statement of architect Michael Graves).

232. AWCPA § 704(a), 17 U.S.C.A. § 120(b) (West Supp. 1992). It should be noted that had this provision uot been passed, owners and clients would still have been able to assign their right to make alterations or to destroy the work, but retain their other copyrights. 
assignment or conveyance must be in writing and signed by the owner of the rights conveyed or the owner's agent. ${ }^{233}$ Although an author may validly assign rights in works not yet created, ${ }^{234}$ a conveyance of rights in all works which the author may thereafter create without any time or other limitation will be held invalid as contrary to public policy. ${ }^{235}$ Assignment of copyright may be validly made through a inortgage. ${ }^{236}$ Banks and other lenders providing construction loans for architectural works in progress may therefore want to include an assignment of copyrights held by the builder, in order for the bank to have the right to complete the work upon default without infringing on the debtor's copyriglit. If the builder does not liave any copyright in the work, a bank slould demand a security imterest in the builder's right of first use of the copyrighted use. ${ }^{237}$

\section{CONCLUSION}

Both art form and utilitarian object, architecture is the paradigm example of a work of apphied art. The AWCPA represents one approach to solving the intellectual property problems presented by useful objects. The subject matter of the AWCPA is broad. All "buildings" enjoy protection. Only those elements of a work that are functionally required are excluded froin protection. This avoids application of the troublesome separability test, the cause of so much confusion in copyright law. In fact, if courts fully accept the architectural maxim that "forn follows function," no elements of an architectural design would be found to be wholly functional.

The more useful an article is, the more likely it is that copyright protection of that article will interfere with its use. Congress anticipated problems, specific to architectural works, that would result from extending full copyright protection to all architectural works. As a result, the broad subject matter category of the AWCPA enjoys only limited protection. Aware of the needs of building owners, Congress provided for the alteration and destruction of arclitectural works. In addition, Congress pernitted two-dimensional reproductions of architectural works. While diluting the rights of an author, these provisions are practical necessities for works that must be altered in order to perform their

233. 17 U.S.C. $\S 204(a)$ (1988).

234. See Bartsch v. Metro-Goldwyn-Mayer, Inc., 391 F.2d 150 (2d Cir.) (upholding assignee's right to televise a play because the assignee had been granted the right to exhibit "motion picture photoplays ... or any process analogous thereto"), cert. denied, 393 U.S. 826 (1968).

235. NIMMER ON COPYRIGHT, supra note 50, § 10.03[A].

236. Id. $\S 10.05$.

237. Altman, supra note 24, at 628-29. 
utilitarian functions and that are visible to the general public. This approach-protection of a broad subject matter, but himited protection for that subject matter, so as not to interfere with the use of those worksmakes good sense for, and should be apphed to, other useful works.

The AWCPA provides architects with greater and more uniform protection for their works than they previously enjoyed. Architects now lave the exclusive right to build from their designs; because reverse engineering now constitutes infringement, architects will release many more of their unexecuted designs. With full copyriglit protection, architects no longer have to rely on contract law to order their rights. The copyright protection afforded by the AWCPA is more effective than contract law, since it does not rely on privity. Moreover, as a federal statute, the AWCPA provides umiform national standards for relief.

The major interpretive questions revolve around the definitions of "functionahty" and "substantial similarity." These terms must be defined in a way that serves the constitutional purpose of the copyright law: to promote progress in the arts and sciences. Architectural progress has always relied upon incremental innovation and the borrowing of elements from existing works. Copyright protection must be evaluated with cognizance of both the needs of the architectural profession, and of the alternative protections offered by trademark law, design patent law, and local historic preservation laws-and with the understanding that creativity in the architectural profession will be hindered, not helped, by overbroad copyright protection. 
FIGURE 1

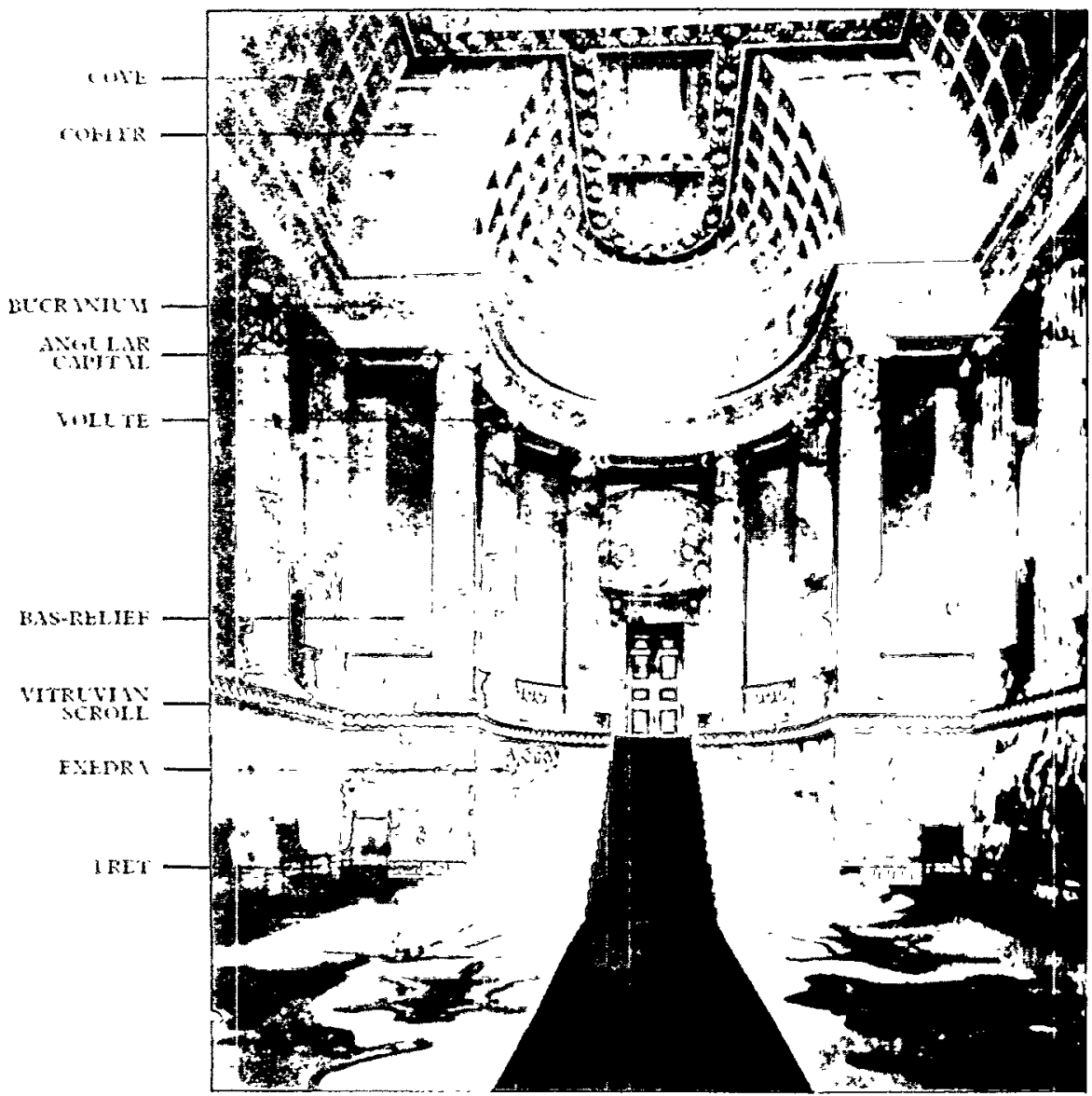

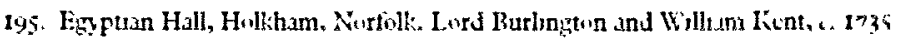

JohN HARRIS \& Jill LeVer, Illustrated GlosSARY OF ARChitecture, 850-1830 plate 195 (1966). Copyright B.T. Batsford Ltd. 
Figure 2

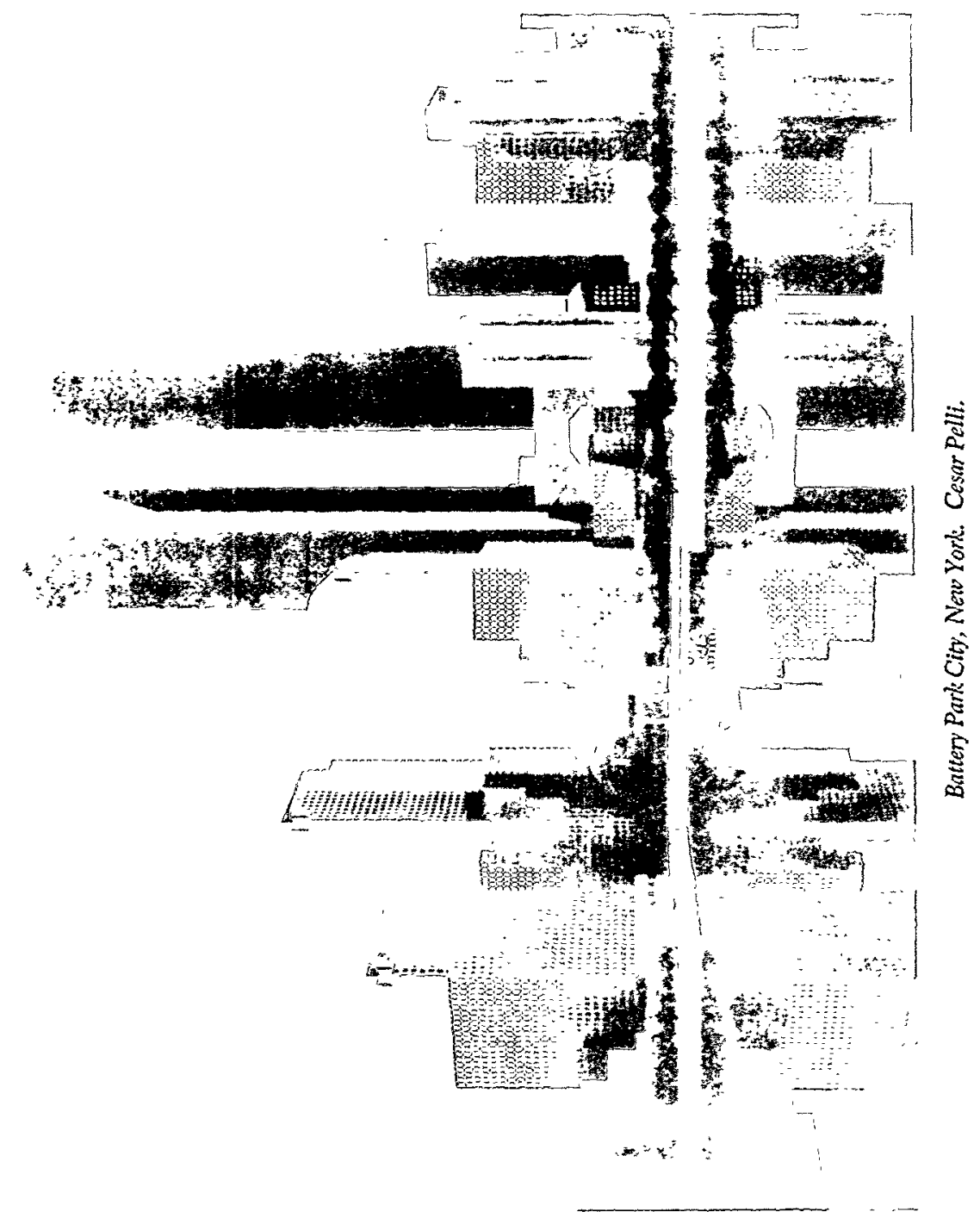

Paul Goldberger, The Skyscraper 159 (1981). Photograph by Kenneth Champlin, courtesy of Cesar Pelli and Associates. 


\section{Figure 3}
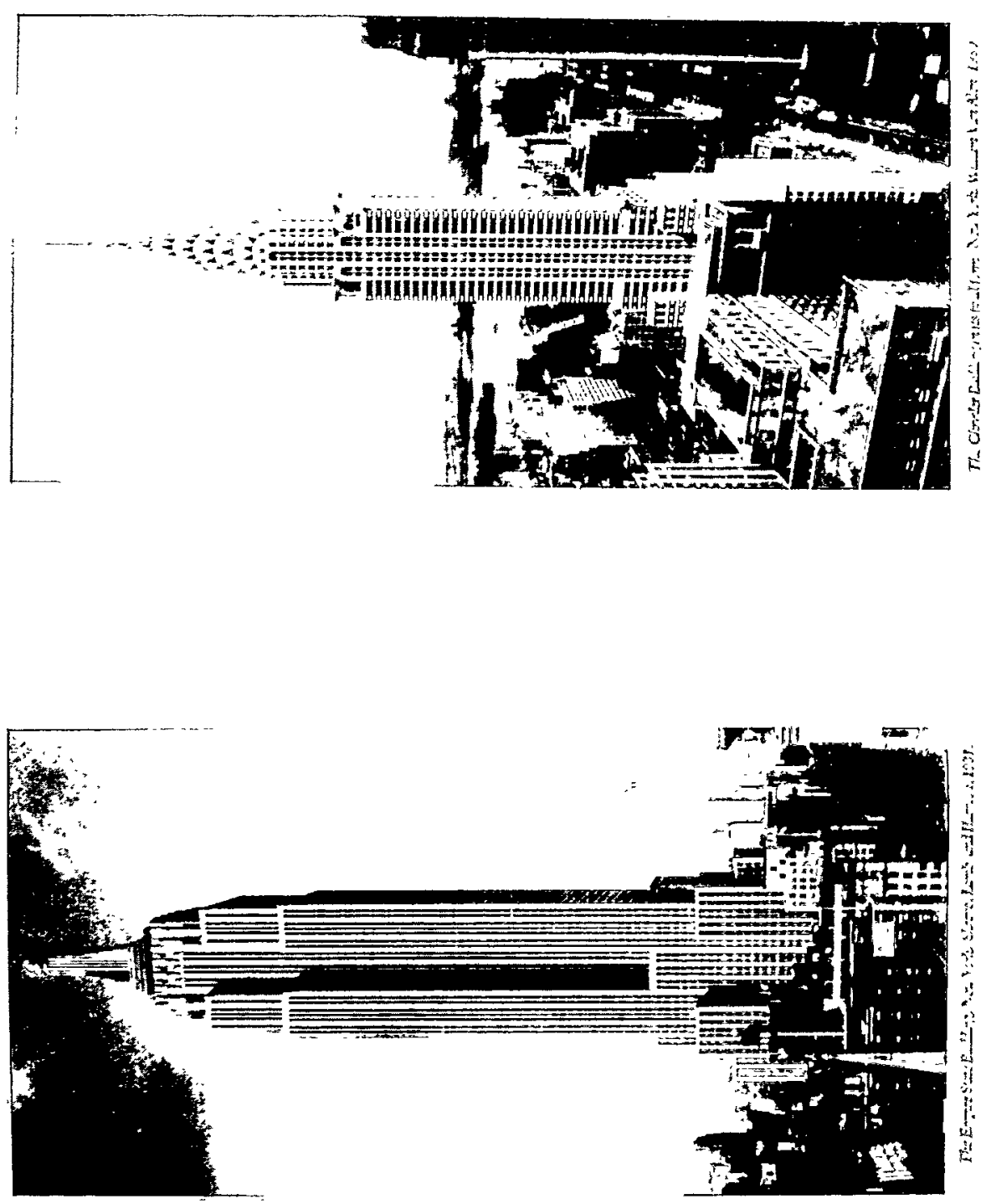

Paul Goldgerger, The SkySCRaPer 81, 84 (1981). Chrysler Building photograph by William Van Alen, courtesy of Wurts Bros.-Photo. Empire State Building photograph courtesy of Wurts Bros. Photo. 
FIGURE 4
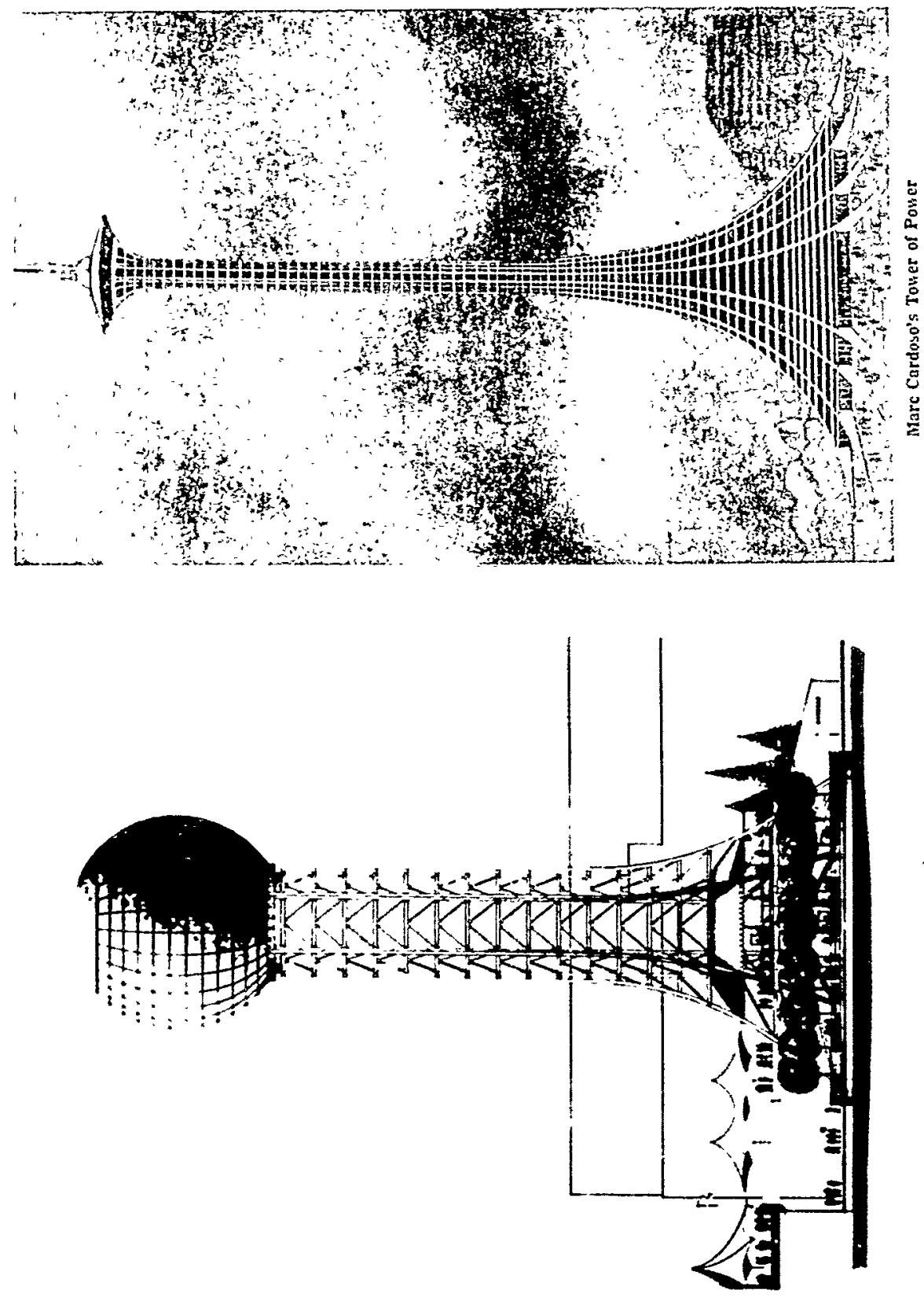

Wickham v. Knoxville Int'l Energy Exposition, Inc., 555 F. Supp. 154, App., Figs. 1, 3 (E.D. Tenn. 1983). 


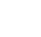

